Article

\title{
Supramolecular Hybrid Material Based on Engineering Porphyrin Hosts for an Efficient Elimination of Lead(II) from Aquatic Medium
}

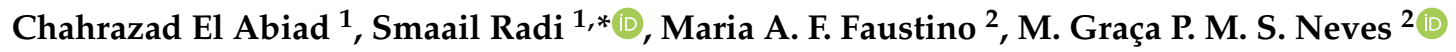 \\ and Nuno M. M. Moura ${ }^{2, *(D)}$ \\ 1 Laboratory of Applied Chemistry and Environment (LCAE), Department of Chemistry, Faculty of Sciences, \\ University Mohamed Premier, Oujda 60000, Morocco; elabiad.1987@gmail.com \\ 2 QOPNA \& LAQV-REQUIMTE, Department of Chemistry, University of Aveiro, 3810-193 Aveiro, Portugal; \\ faustino@ua.pt (M.A.F.F.); gneves@ua.pt (M.G.P.M.S.N.) \\ * Correspondence: s.radi@ump.ac.ma (S.R.); nmoura@ua.pt (N.M.M.M.); Tel.: +351-234-370-710 (N.M.M.M.) \\ Academic Editor: Derek J. McPhee \\ Received: 14 January 2019; Accepted: 11 February 2019; Published: 14 February 2019

\begin{abstract}
Porphyrins show great promise for future purification demands. This is largely due to their unique features as host binding molecules that can be modified at the synthetic level, and largely improved by their incorporation into inorganic based materials. In this study, we assessed the efficacy of a hybrid material obtained from the immobilization of 5,10,15,20-tetrakis(pentafluorophenyl)-porphyrin on silica surface to remove $\mathrm{Pb}$ (II), $\mathrm{Cu}$ (II), $\mathrm{Cd}$ (II), and $\mathrm{Zn}$ (II) ions from water. The new organic-inorganic hybrid adsorbent was fully characterized by adequate techniques and the results show that the hybrid exhibits good chemical and thermal stability. From batch assays, it was evaluated how the efficacy of the hybrid was affected by the $\mathrm{pH}$, contact time, initial metal concentration, and temperature. The adsorption kinetic and isotherms showed to fit the recent developed fractal-like pseudo-second-order model and Langmuir-Freundlich model respectively. The highest adsorption capacities for $\mathrm{Pb}(\mathrm{II}), \mathrm{Cu}(\mathrm{II}), \mathrm{Cd}(\mathrm{II})$, and $\mathrm{Zn}(\mathrm{II})$ ions were $187.36,125.17,82.45$, and $56.23 \mathrm{mg} \mathrm{g}^{-1}$, respectively, at $\mathrm{pH} 6.0$ and $25^{\circ} \mathrm{C}$. This study also shows that metal cations from real river water samples can be efficient removed in the presence of the new adsorbent material.
\end{abstract}

Keywords: porphyrinoids; hybrid material; adsorption; heavy metal cation; selectivity; lead

\section{Introduction}

The high number of applications involving potentially toxic metal ions is being associated to an increase of metallic substances present in the environment. The beneficial impact of the industrial revolution has been in many aspects accompanied by a negative impact in the environment. For instance, the direct discharge of industrial effluents in watercourses is making them unsuitable for living organism consumption and even for domestic and irrigation use. Heavy metal ions are pointed out as one of the most dangerous inorganic contaminants present in polluted water and are being associated to many health effects [1-3]. Long-term exposure to potentially toxic metals ions, such as $\mathrm{Pb}(\mathrm{II}), \mathrm{Cu}(\mathrm{II}), \mathrm{Cd}(\mathrm{II})$, or $\mathrm{Zn}$ (II) are being associated with liver and kidney damage, lung cancer, reduction in hemoglobin formation, emphysema, hypertension, testicular atrophy diseases or itching $[4,5]$.

Heavy metal ions are highly poisonous and can be found in discharged waters from several industries, such as coating, storage batteries, and aeronautical. Furthermore, it may leach into drinking water from certain types of plumbing materials. These metal ions can be responsible for serious 
health effects like hypertension, muscle and joint pain, irritability, memory or concentration problems, kidney failure, and nervous diseases [3,6]. Therefore, in recent years, a high number of studies have been related with the removal of potentially toxic metals from contaminated water, namely industrial wastewater. In addition, an important investment has been dedicated to improve techniques related with wastewater treatment namely conventional physicochemical methods, such as reverse osmosis [7], flotation [8], coagulation [9], ion exchange [10], chemical precipitation [11], membrane filtration [12], and adsorption [13,14]. Between them, adsorption is considered a promising and widely used approach. Among the different materials capable of capturing metal ions, aqueous solutions are included activated carbon [15], fly ash [16], microbial biomass [17], and biomass materials [18,19]. However, these materials have shown some disadvantages, such as weak chemical bonds, limited removal efficiency, high cost, and low mechanical and thermal stability [20].

On the other hand, materials based in silica gel have many advantages, due to their good mechanical and thermal stability, high porosity, and good swelling resistance in the presence of different solvents. Additionally, their surfaces can be easily modified by using different approaches [21-23].

Recently, an important topic of research has been related to the development of silica gel based organic-inorganic hybrid materials for the removal of heavy metal ions [24-29]. Silica gel is considered an ideal inorganic solid matrix, not only due to its surface property, but also to its relative simplicity, when compared with polymer resins. So, a high number of chemically modified silica gels have been prepared, and in general, their adsorption properties are mainly dependent on the presence of active donor atoms, like sulfur, oxygen and nitrogen, of the incorporated organic units [30,31].

In this context, porphyrins, well-known by their highly intense colors and key roles in basic mechanisms of living organisms are considered a special class of heterocyclic ligands, due to their unique properties, namely a high ability to coordinate a wide range of metal ions affording stable complexes [32-38]. In fact, the porphyrin capacity to recognize specific analytes has attracted the attention of the scientific community in the chemical sensing field, due to a possible selectivity enhancement involving supramolecular chemistry concepts [34,39]. These porphyrins can host, through their backbone and inner core, analytes according to various mechanisms, including hydrogen bonds, Van der Waals forces, $\pi-\pi$ interactions, and coordination $[33,40]$. In particular, the inner nitrogen donor atoms are able to interact with a wide range of metal ions, and therefore, allow for their detection or elimination with high efficiency [41].

The access to porphyrins with adequate properties for a special application can be easily tuned by structural modifications at different stages of the porphyrin synthesis [42]. One of the strategies can involve the post-functionalization of the porphyrin macrocycle by attachment to additional groups. In this context, 5,10,15,20-tetrakis(pentafluorophenyl) porphyrin $\left(\mathbf{H}_{\mathbf{2}} \mathbf{T} \mathbf{F}_{5} \mathbf{P P}\right)$, has revealed to be a versatile template to afford new porphyrin derivatives for a wide range of applications [43-48]. In fact, the reaction of $\mathbf{H}_{\mathbf{2}} \mathbf{T} \mathbf{F}_{\mathbf{5}} \mathbf{P P}$, or of the corresponding metal complexes, with nucleophiles is considered a simple and general strategy to afford meso-tetraarylporphyrins functionalized at the para position of their meso-aryl groups with electron-donating substituents. In addition, the selective substitution of the para-F atoms occurs frequently with high yield [49].

In this paper, the synthesis and the characterization of an inorganic-organic hybrid material obtained by the covalent attachment of $\mathbf{H}_{2} \mathbf{T} \mathbf{F}_{5} \mathbf{P P}$ on silica, and its use in potentially toxic metal ions removal, is assessed by considering the importance of developing efficient metal adsorbents. All parameters that may affect the adsorption efficiency of metal ions (e.g., pH, contact time, and concentration) have been studied. The ability of the adsorbent to remove metal cations from real water samples, as well as its reusability, was evaluated and compared with the extracted quantities of metals ions determined by atomic absorption measurements. 


\section{Results and Discussion}

\subsection{Synthesis and Characterization of the Organic-Inorganic Hybrid Material SiTF ${ }_{5} P P$}

The synthetic procedure giving rise to the organic-inorganic hybrid material $\mathbf{S i T F}_{\mathbf{5}} \mathbf{P P}$ is outlined in Scheme 1. The first step involved the decoration of the activated silica Si with amino groups, through its reaction with 3-aminopropyltrimethoxysilane in toluene. The second step, comprising the reaction between the obtained amino functionalized silica material SiPn and the porphyrinic ligand 5,10,15,20-tetrakis(pentafluorophenyl)porphyrin $\left(\mathbf{H}_{\mathbf{2}} \mathbf{T} \mathbf{F}_{\mathbf{5}} \mathbf{P P}\right)$, was performed in refluxing toluene for $48 \mathrm{~h}$.
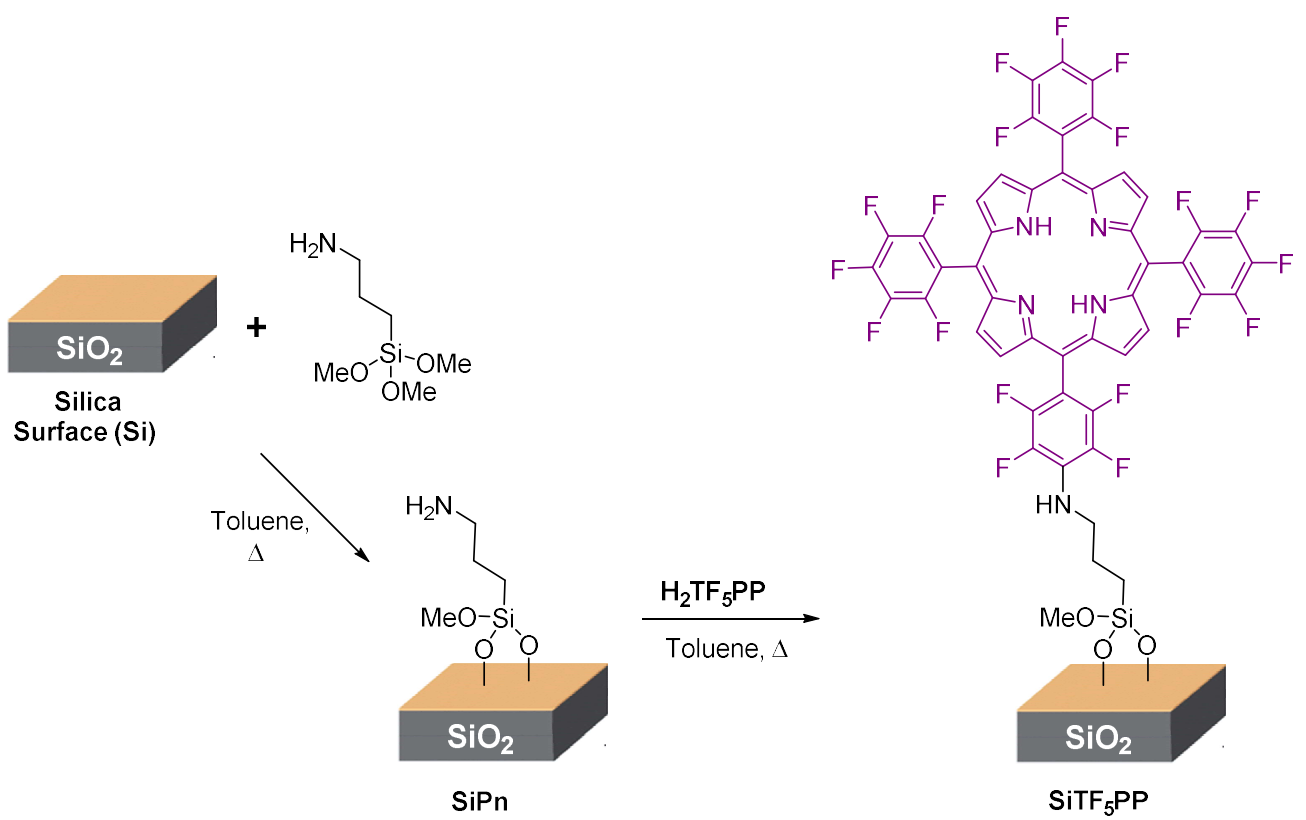

Scheme 1. Synthetic methodology used to prepare the inorganic-organic hybrid $\mathbf{S i T F}_{5} \mathbf{P P}$.

The properties and morphology of the synthesized adsorbent material were studied by using the appropriate techniques like elemental analysis (EA), attenuated total reflection-fourier transform infra-red (ATR-FTIR), powder X-ray diffraction (XRD), scanning electron microscopy (SEM) and transmission electron microscopy (TEM), ${ }^{13} \mathrm{C}$ solid-state CPMAS NMR, Brunauer-Emmett-Teller (BET) surface area and Barrett-Joyner-Halenda (BJH) analysis, thermogravimetric analysis (TGA), and solid-state UV-Vis.

The success of the two synthetic steps was clearly confirmed by elemental analysis (see Table S1 in Electronic Supplementary Information, ESI). The presence of carbon and nitrogen in SiPn indicates that the aminopropylation reaction was successfully accomplished, since neither element is present in native silica. The increase in the content of carbon in SiTF5PP, when compared with SiPn (C, 8.00\%; $\mathrm{N}, 1.53 \%$ verus C, 5.03\%; N, 1.63\%), indicates that the porphyrin was attached to SiPn. The ATR-FTIR spectra of the starting material Si, the materials SiPn and $\mathbf{S i T F}_{5} \mathbf{P P}$ are shown in Figure S1 in the ESI. For $\mathrm{Si}$, the broad and intense peak at $c a 3462 \mathrm{~cm}^{-1}$ can be ascribed to the $\mathrm{O}-\mathrm{H}$ stretching vibration of the silanol group. The intense bands at $1638 \mathrm{~cm}^{-1}$ and at $1096 \mathrm{~cm}^{-1}$ are attributed to the stretching vibration of $\mathrm{Si}-\mathrm{OH}$ and $\mathrm{Si}-\mathrm{O}-\mathrm{Si}$, respectively, while the bands at $c a .972 \mathrm{~cm}^{-1}$ result from the Si-O vibration [50].

In the spectrum of SiPn, new bands at $2979 \mathrm{~cm}^{-1}$ and $1563 \mathrm{~cm}^{-1}$ are observed, which can be attributed to $v(\mathrm{C}-\mathrm{H})$, and $v\left(\mathrm{NH}_{2}\right)$, stretching vibrations, respectively [51]. These bands are indicative of the presence of 3-aminopropylsilane units on silica particle surface. The ATR-FTIR spectra of the hybrid material SiTF5PP reveals the disappearance of the band at $1563 \mathrm{~cm}^{-1}$, due to the reaction of the primary amine groups $\left(-\mathrm{NH}_{2}\right)$, and the appearance of new bands in the range $1503-1450 \mathrm{~cm}^{-1}$ and 
at $802 \mathrm{~cm}^{-1}$. This is due to the valence vibrations of $C-C$ bonds of pentafluorophenyl substituents and of the porphyrinic macrocycle [52]. Moreover, new characteristic bands around $1532 \mathrm{~cm}^{-1}$ and 1468 $\mathrm{cm}^{-1}$ resulted from $v(\mathrm{C}=\mathrm{N})$, and $v(\mathrm{C}=\mathrm{C})$ vibrations, respectively.

The modification in morphological features, after the silica surface functionalization, was clarified using SEM (Figure 1). The surface of the native silica $\mathbf{S i}$, that was initially smooth, becomes rough after functionalization. Moreover, the immobilized surface $\mathbf{S i T F}_{5} \mathbf{P P}$ tends to be partially aggregated due to the presence of a high amount of the organic component. This morphology was confirmed using scanning transmission electron microscopy (STEM), which is very sensitive to variations of surface structure. Indeed, a rough surface is clearly highlighted in the STEM micrograph as shown in Figure $1 \mathrm{~d}$. These results confirm the successful anchorage of the porphyrin unit at silica surface, and it is known that a rough surface can be beneficial to metal ion adsorption.

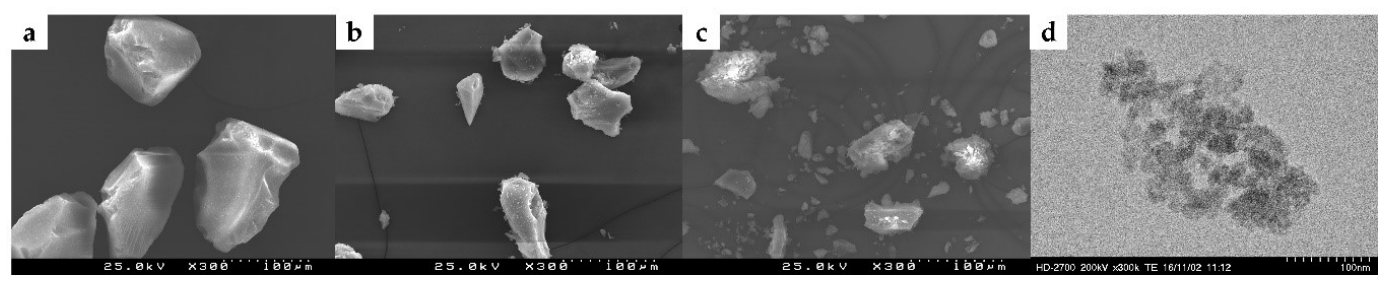

Figure 1. SEM images of free silica $\mathbf{S i}(\mathbf{a}), \mathbf{S i P n}(\mathbf{b})$ and $\mathbf{S i T F}_{5} \mathbf{P P}(\mathbf{c})$ and scanning transmission electron microscopy (STEM) image of $\operatorname{SiTF}_{5} \mathbf{P P}(\mathbf{d})$.

The presence of the porphyrin moiety in the final hybrid material $\mathbf{S i T F}_{5} \mathbf{P P}$ was also confirmed by ${ }^{13} \mathrm{C}$ solid-state CPMAS NMR (Figure S2 in ESI). The ${ }^{13} \mathrm{C}$ spectrum of SiPn shows signals at $\delta$ $9.75, \delta 22.06$, and $\delta 42.66 \mathrm{ppm}$, due to the resonances of the aliphatic propyl carbons $\mathrm{Si}-\mathrm{CH}_{2},-\mathrm{CH}_{2}-$, and $\mathrm{N}-\mathrm{CH}_{2}$, respectively. In the same region "a", the signal at $\delta 50.96 \mathrm{ppm}$ is assigned to the resonance of the non-substituted methoxy group $\left(-\mathrm{OCH}_{3}\right)$. The additional peaks that appear in the ${ }^{13} \mathrm{C}$ spectrum of $\mathbf{S i T F}_{5} \mathbf{P P}$ in the low field region are categorized as "b" between $\delta \cong 106$ and $\delta \cong 165 \mathrm{ppm}$, due to the aromatic carbon resonances of the porphyrin macrocycle.

The thermal stability of the new hybrid material $\mathbf{S i T F}_{5} \mathbf{P P}$ was evaluated by thermogravimetric analysis, and it was compared with the thermal stability of the precursors Si and SiPn (Figure 2). The TGA of all the studied materials exhibited a mass loss below $110^{\circ} \mathrm{C}$, assigned to the loss of the physically adsorbed of water [53]. The native Si shows a second mass loss up to $800{ }^{\circ} \mathrm{C}$ assigned to condensation of free silanol groups bonded to the surface [54]. Similar to the native silica (Si), SiPn and $\mathrm{SiTF}_{5} \mathbf{P P}$ also show additional mass losses, due to the decomposition of the organic groups decorating the silica surface [55-57]. These data indicated that the adsorbent $\mathbf{S i T F}_{5} \mathbf{P P}$ has good thermal stability and the immobilization of the porphyrin macrocycle was accomplished with success.

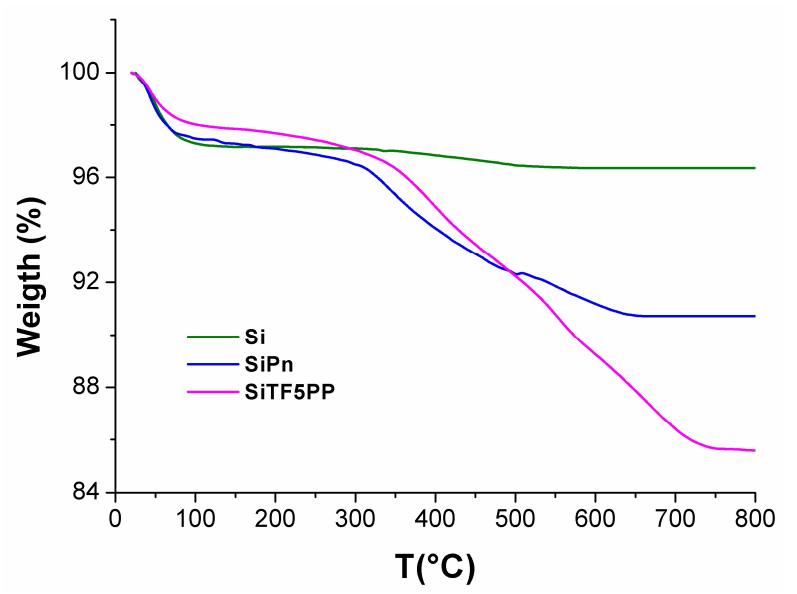

Figure 2. Thermogravimetric curves of $\mathrm{Si}, \mathrm{SiPn}$ and $\mathrm{SiTF}_{5} \mathrm{PP}$. 
In order to evaluate how the surface and porosity of the activated silica were changed after the introduction of 3-amino-propyl and $\mathbf{H}_{2} \mathbf{T} \mathbf{F}_{5} \mathbf{P P}$, the surface area SBET (Brunauer-Emmett-Teller), and the pore diameters and pore volumes of native silica, $\mathbf{S i}$, SiPn, and $\mathbf{S i T F}_{5} \mathbf{P P}$, were determined using nitrogen adsorption-desorption isotherms, and Barrett-Joyner-Halenda (BJH) methods, respectively (Figure 3) [58,59]. It is important to highlight that the isotherm curves for all materials (Figure 3) are type IV according to the classification of IUPAC, showing that partial pressures $\left(\mathrm{P} / \mathrm{P}_{0}>0.4\right)$ are a pronounced hysteresis, which is clear evidence of the mesoporous nature of the materials. In addition, the hysteresis loops are type $\mathrm{H} 2$, thereby indicating a uniform pore diameter distribution. The median pore size distribution $(<50 \AA)$ also confirms the uniform framework mesoporosity of the materials. Table 1 summarizes the physical parameters calculated from nitrogen adsorption-desorption isotherms. It was observed that SiPn decreased in surface area, total pore volume, and pore diameter compared with the initial Si. These results can be justified by taking into account the introduction of the organic functionalities into the mesoporous channels, which may diminish the pore size and increase the density of the material [54,60-62]. The increase in the surface area of $\mathbf{S i T F}_{5} \mathbf{P P}$, relative to SiPn, is presumably due to the increasing surface roughness, as it was verified by SEM imaging. In addition, the pore volumes and the pore diameters remain unchanged, suggesting that the grafted porphyrins are located, not inside the pores, but rather on the outer surface, which confirms its further increase.
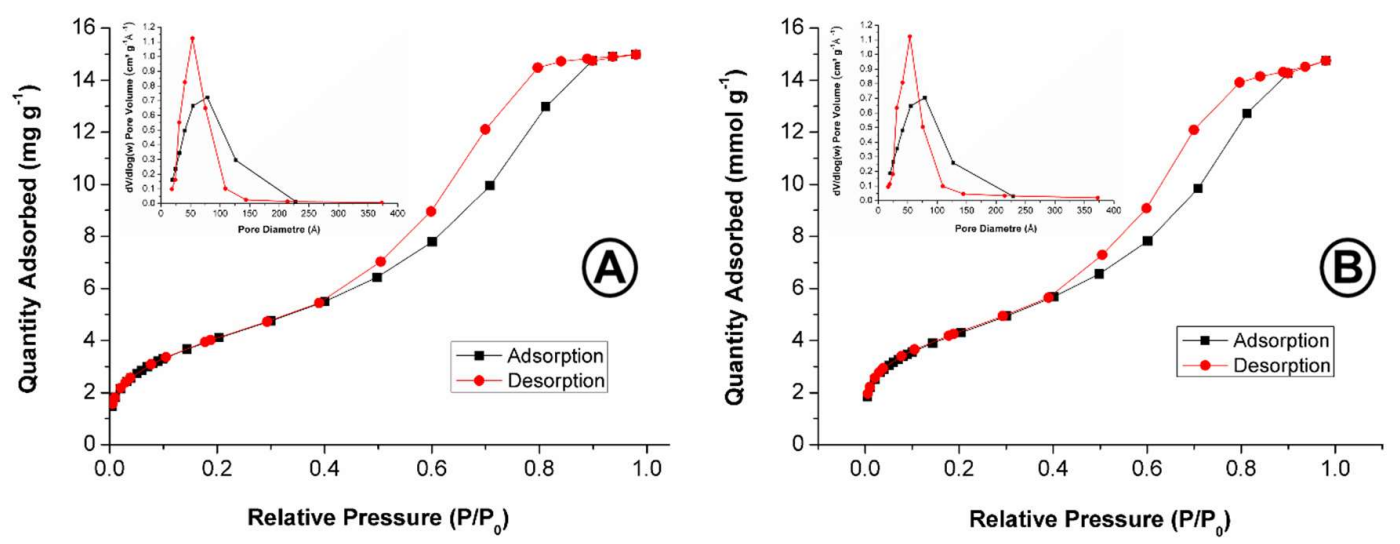

Figure 3. Nitrogen adsorption-desorption isotherm at $77 \mathrm{~K}$ plots of $\mathbf{S i P n}(\mathbf{A})$ and $\mathbf{S i T F}_{5} \mathbf{P P}(\mathbf{B})$. Inset is given the respective $\mathrm{BJH}$ pore size distribution curves.

Table 1. Physical properties of silica-based materials.

\begin{tabular}{|c|c|c|c|}
\hline Materials & $\begin{array}{l}\text { Specific Surface } \\
S_{B E T}\left(\mathrm{~m}^{2} \mathrm{~g}^{-1}\right)\end{array}$ & $\begin{array}{l}\text { Pore Volume } \\
\left(\mathrm{cm}^{3} \mathrm{~g}^{-1}\right)\end{array}$ & $\begin{array}{l}\text { Average Pore } \\
\text { Diameter (Å) }\end{array}$ \\
\hline Si & $434.6526 \pm 4.6197$ & $0.671 \pm 0.002$ & 47.882 \\
\hline SiPn & $328.7584 \pm 5.5689$ & $0.482 \pm 0.003$ & 46.358 \\
\hline $\mathrm{SiTF}_{5} \mathrm{PP}$ & $341.8908 \pm 4.0805$ & $0.477 \pm 0.010$ & 46.307 \\
\hline
\end{tabular}

The XRD pattern of the $\mathbf{S i T F}_{5} \mathbf{P P}$ hybrid has been studied in the $2 \theta$ range of 5 to 50 and was compared with the XRD patterns of the activated silica $\mathbf{S i}$, and of the aminopropyl functionalized silica SiPn. The XRD patterns summarized in Figure S3 (ESI) indicate that the materials prepared had maintained the mesoporous structure without significant impairment after modification. All diffractograms show the characteristic broad peak at low $2 \theta$ angle range due to the pore family (100) indicating a well-ordered type material [63]. Additionally, there is another weak broad peak (110) at a high $2 \theta$ angle (at about $23^{\circ}$ ), which is typical of amorphous silica, without peaks being assignable to any crystalline phase [63]. No significant changes on silica functionalization were observed, but as already indicated for other hybrid materials [64], the XRD peak intensity decreased in the case 
of the grafted samples, when compared to the initial silica. These results prove that the successful functionalization of the silica surface occurs mainly inside the mesopore channels.

The successful anchorage of $\mathbf{H}_{2}$ TF5PP to the matrix functionalized with amino groups was also confirmed by solid-state UV-Vis spectrophotometry. The UV-V is the absorption spectrum of the hybrid material $\mathbf{S i T F}_{5} \mathbf{P P}$, which shows the typical broad absorption bands of the free-base porphyrin $\mathbf{H}_{2} \mathbf{T F}_{5} \mathbf{P P}$ in the solid state (Figure 4). The band broadening and the baseline elevation, observed in the solid UV-Vis of the hybrid, $\mathbf{S i T F}_{5} \mathbf{P P}$, are due to the presence of solid-state interactions between the macrocycle and the silica [65].

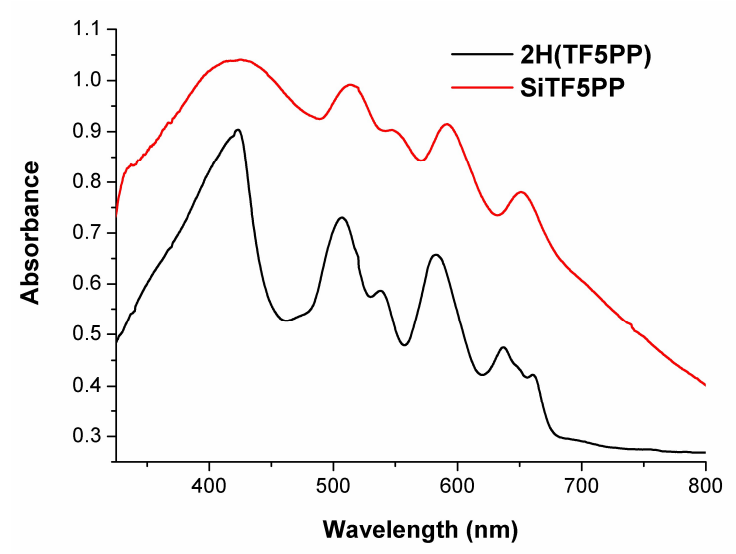

Figure 4. Solid-state UV-Vis spectra of $\mathbf{H}_{2} \mathrm{TF}_{5} \mathbf{P P}$ and of the hybrid $\mathrm{SiTF}_{5} \mathbf{P P}$.

The chemical stability of the newly synthesized hybrid $\mathbf{S i T F}_{5} \mathbf{P P}$ was investigated in the $\mathrm{pH}$ range 1 to 7 , in acidic and buffer solutions. After acid treatment, the material structure remains unchanged as it was examined by elemental analysis $(\% \mathrm{C}=8.00 \pm 0.20)$. The high stability presented by the attached organofunctional substituent is presumably due to the pendant chain responsible by the linkage between the amine and the $\mathbf{H}_{2} \mathbf{T F}_{5} \mathbf{P P}$ into the silica surface. It has been reported that when the length of the hydrocarbon bridge contains more than two methylene groups, the cleavage of $\mathrm{Si}-\mathrm{C}$ bond is minimized under acidic medium, since these longer chains do not hold a functional handle that can undergo $\beta$-elimination of the Si cation $[66,67]$.

\subsection{Metal Cations Adsorption}

\subsubsection{Effect of $\mathrm{pH}$}

It is well known that the $\mathrm{pH}$ value is an important factor affecting the removal of cations from aqueous solutions. The $\mathrm{pH}$ dependence of metal sorption is related to the chemistry of the metal in solution and also with the ionization state of the functional groups present in adsorbent, which can affect the availability of binding sites. Under this context, the adsorption capability of SiTF5PP towards $\mathrm{Pb}(\mathrm{II}), \mathrm{Cu}(\mathrm{II}), \mathrm{Cd}(\mathrm{II})$ and $\mathrm{Zn}(\mathrm{II})$ was determined in aqueous solutions with $\mathrm{pH}$ ranging between 1 and 7 as it is summarized in Figure 5. 


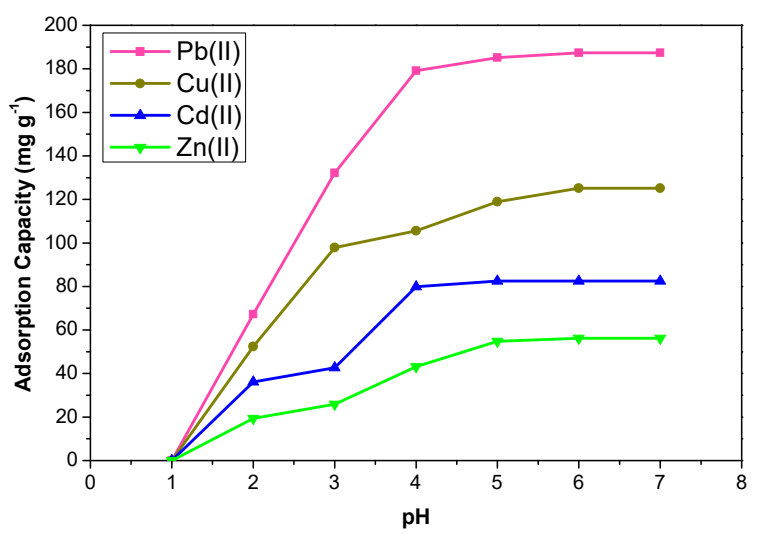

Figure 5. Effect of $\mathrm{pH}$ on the adsorption of studied metal ions on $\mathbf{S i T F}_{5} \mathbf{P P}$. Adsorption dose: $\mathrm{V}=10 \mathrm{~mL}$, $\mathrm{m}=10 \mathrm{mg}$ of $\mathbf{S i T F}_{5} \mathbf{P P}$ at optimum concentration (187.36 ppm in each case), $\mathrm{t}=30 \mathrm{~min}$ and $25^{\circ} \mathrm{C}$. Lines just combine the points.

The results showed that at lower $\mathrm{pH}$ values, the metal cation retention is not significant, since the porphyrinic receptor is in its dicationic form and consequently unable to coordinate the metal cation. However, the data show that the deprotonation favors the adsorption and the best retention values were observed at $\mathrm{pH}$ 6-7 for the metal cations $\mathrm{Pb}$ (II), $\mathrm{Cu}$ (II), $\mathrm{Zn}$ (II), while for $\mathrm{Cd}$ (II) occur in the range 5-7. At $\mathrm{pH}$ values higher than 7, it is difficult to distinguish between the $\mathrm{M}$ (II) hydrolyzed or adsorbed, due to the precipitation of hydroxides, resulting from the metal ion hydrolysis. So, the other studies concerning the parameters that can affect the sorption efficiency of the metal ions were performed at pH 6.

\subsubsection{Effect of Contact Time and Adsorption Kinetics}

The results depicted in Figure 6, show that the adsorption efficacy of $\mathbf{S i T F}_{5} \mathbf{P P}$ towards the different metal ions is strongly dependent on its contact time with the analytes until the equilibrium conditions are attainment. The effect of contact time on the adsorption of $\mathrm{Pb}(\mathrm{II}), \mathrm{Cu}(\mathrm{II}), \mathrm{Cd}(\mathrm{II})$, and $\mathrm{Zn}$ (II) by SiTF $_{5} \mathbf{P P}$ was studied by batch experiments, and the kinetic curves show a fast adsorption in the first 5 min reaching a plateau after about 25 min of contact. These prompt interactions with the free metal cations present in aqueous solution suggest that the porphyrinic units are adequately oriented and accessible, allowing the required incorporation of the metal cation in the macrocycle inner core.

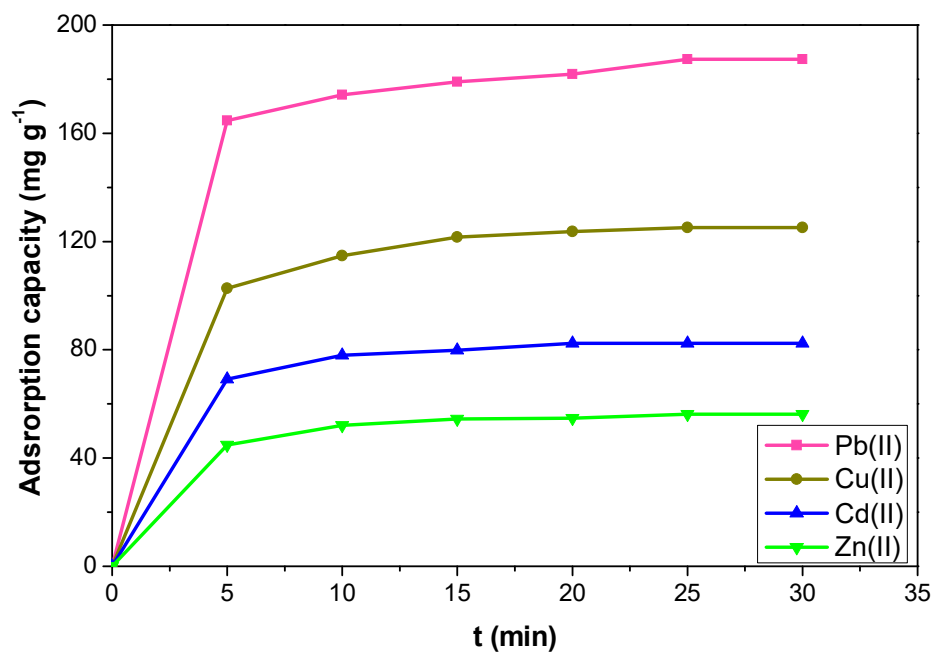

Figure 6. Effect of contact time on $\mathrm{SiTF}_{5} \mathbf{P P}$ adsorption capacity towards $\mathrm{Pb}(\mathrm{II}), \mathrm{Cu}(\mathrm{II}), \mathrm{Cd}(\mathrm{II})$, and $\mathrm{Zn}(\mathrm{II})$. Adsorption dose: $\mathrm{V}=10 \mathrm{~mL}, \mathrm{~m}=10 \mathrm{mg}$ of $\mathbf{S i T F}_{5} \mathbf{P P}$, at optimum $\mathrm{pH}(\mathrm{pH}=6), 25^{\circ} \mathrm{C}$ and optimum concentration (187.36 ppm in each case). Lines just combine the point. 
The superior efficacy of $\mathbf{S i T F}_{5} \mathbf{P P}$, when compared with a previous material obtained from the immobilization of 2-formyl-5,10,15,20-tetraphenylporphyrin in silica (SiNTPP), previously described by us [68], (see Table 7 ) can be a consequence of the linkage position ( $\beta$-pyrrolic versus meso-position) combined with the electronic features of the meso-substituents (pentafluorophenyl versus phenyl groups).

Usually, the coordination of porphyrins with divalent metals occurs via the initial formation of a sitting-atop (SAT) porphyrin complex [69], where the metal ion interacts with the macrocycle inner nitrogen atoms without the simultaneous deprotonation of the $\mathrm{N}-\mathrm{H}$ group. Depending on the size of the metal ion and on its spin multiplicity, a further step can happen involving the deprotonation of the two $\mathrm{N}-\mathrm{H}$ groups, which is accompanied by the metal incorporation into the macrocycle core. The different metal selectivities can be justified, by considering the activation energy of the rate-limiting step for each metal ion $[69,70]$.

So, in the case of $\mathbf{S i T F}_{5} \mathbf{P P}$, the mesomeric electron-donor (+M) effect of the fluorine atoms can play a crucial role in the initial step by increasing the electronic density present on the non-protonated nitrogen atoms (see Figure S4, ESI). On the other hand, the fluorine inductive electron-withdrawing effect cans beneficiate the loss of two $\mathrm{N}-\mathrm{H}$ protons of the second step.

So, the great benefit of porphyrinic derivatives is the easy adaptation of their core to the metal ion size. These macrocycles are able to respond in different manners to a mismatch in size involving the macrocycle cavity $(2.03 \pm 0.8 \AA)$ and the metal ion $[(1.19 \AA) \mathrm{Pb}(\mathrm{II}),(0.73 \AA) \mathrm{Cu}(\mathrm{II}),(0.95 \AA) \mathrm{Cd}(\mathrm{II})$, and (0.74 $\AA$ ) $\mathrm{Zn}(\mathrm{II})$ ] [71]. Actually, the bonds are able to stretch, or to compress, depending on the metal cation sizes, as it was previously reported for the metal cations under evaluation [72].

In fact, the results given in Table 2 confirm the importance of the porphyrin receptor immobilized onto silica surface on heavy metal adsorption. The free silica (Si) and 3-aminopropylsilica (SiPn) show only negligible adsorption when compared with the high metal uptake adsorption observed for $\mathrm{SiTF}_{5} \mathrm{PP}$.

Table 2. Metal ion adsorption of $\mathbf{S i}, \mathbf{S i P n}$ and $\mathbf{S i T F}_{5} \mathbf{P P}$ as contact time (30 min) function.

\begin{tabular}{ccccc}
\hline Material & \multicolumn{4}{c}{$\boldsymbol{q}_{e} \pm \mathbf{1 . 0}\left(\mathbf{m g ~ g}^{\mathbf{- 1}}\right)$} \\
\hline & $\mathrm{Pb}(\mathrm{II})$ & $\mathrm{Cu}(\mathrm{II})$ & $\mathrm{Cd}(\mathrm{II})$ & $\mathrm{Zn}(\mathrm{II})$ \\
$\mathbf{S i}$ & 4.35 & 4.58 & 3.26 & 6.89 \\
$\mathrm{SiPn}$ & 6.34 & 5.32 & 6.57 & 7.86 \\
$\mathrm{SiTF}_{5} \mathbf{P P}$ & 187.36 & 125.16 & 82.44 & 56.23 \\
\hline
\end{tabular}

In order to understand the mechanism behind the adsorption process, a theoretical analysis of the data obtained was undertaken using equation 1 for a pseudo-first-order model and equation 2 for a pseudo-second-order model [73]:

$$
\begin{gathered}
\mathrm{q}_{\mathrm{t}}=\mathrm{q}_{\mathrm{e}}\left[1-\mathrm{e}^{-\mathrm{k}_{1} \mathrm{t}}\right] \\
\mathrm{q}_{\mathrm{t}}=\frac{\mathrm{k}_{2} \mathrm{q}_{\mathrm{e}}^{2} \mathrm{t}}{1+\mathrm{k}_{2} \mathrm{q}_{\mathrm{e}} \mathrm{t}}
\end{gathered}
$$

where $\mathrm{q}_{\mathrm{t}}$ and $\mathrm{q}_{\mathrm{e}}$ are the amounts of metal cations adsorbed $\left(\mathrm{mg} \mathrm{g}^{-1}\right)$ at time $\mathrm{t}$, and at equilibrium, respectively, and $\mathrm{k}_{1}$, and $\mathrm{k}_{2}$, are the adsorption rate constants of the first- and second-order, respectively. The results of pseudo-first-order and pseudo-second-order parameters are given in Table 3. 
Table 3. Kinetics of heavy metals removal onto SiTF $_{5} \mathbf{P P}$.

\begin{tabular}{|c|c|c|c|c|}
\hline \multirow[t]{2}{*}{ Parameters } & \multicolumn{4}{|c|}{ Metals } \\
\hline & $\begin{array}{c}\mathrm{Pb}(\mathrm{II}) \\
(1.19 \AA)\end{array}$ & $\begin{array}{c}\mathrm{Cu}(\mathrm{II}) \\
(0.73 \AA)\end{array}$ & $\begin{array}{c}\mathrm{Cd}(\mathrm{II}) \\
(0.95 \AA)\end{array}$ & $\begin{array}{c}\mathrm{Zn}(\mathrm{II}) \\
(0.74 \AA \AA)\end{array}$ \\
\hline $\mathrm{q}_{\mathrm{e}}(\exp )\left(\mathrm{mg} \mathrm{g}^{-1}\right)$ & $187.36 \pm 1$ & $125.17 \pm 1$ & $82.45 \pm 1$ & $56.23 \pm 1$ \\
\hline \multirow[t]{2}{*}{$\mathrm{q}_{\mathrm{e}}(\exp )\left(\mathrm{mmol} \mathrm{g}^{-1}\right)$} & 0.90 & 1.97 & 0.73 & 0.86 \\
\hline & \multicolumn{4}{|c|}{ Pseudo-first-order } \\
\hline $\begin{array}{c}\mathrm{qe}_{\mathrm{e}} \\
\left(\mathrm{mg} \mathrm{g}^{-1}\right)\end{array}$ & $182.695 \pm 2.095$ & $123.393 \pm 1.223$ & $81.634 \pm 0.568$ & $55.390 \pm 0.412$ \\
\hline $\begin{array}{c}\mathrm{q}_{\mathrm{e}} \\
\left(\mathrm{mmol} \mathrm{g}^{-1}\right)\end{array}$ & 0.881 & 1.943 & 0.726 & 0.847 \\
\hline $\mathrm{k}_{1}\left(\min ^{-1}\right)$ & $0.447 \pm 0.50$ & $0.340 \pm 0.024$ & $0.365 \pm 0.019$ & $0.322 \pm 0.016$ \\
\hline \multirow[t]{2}{*}{$\mathrm{R}^{2}$} & 0.996 & 0.997 & 0.998 & 0.998 \\
\hline & \multicolumn{4}{|c|}{ Pseudo-second-order } \\
\hline$\left(\begin{array}{c}\mathrm{q}_{\mathrm{e}} \\
\left(\mathrm{mg}^{-1} \mathrm{~g}\right)\end{array}\right.$ & $191.205 \pm 1.613$ & $132.122 \pm 0.651$ & $83.641 \pm 0.572$ & $59.644 \pm 0.455$ \\
\hline $\begin{array}{c}\mathrm{qe}_{\mathrm{e}} \\
\left(\mathrm{mmol} \mathrm{g}^{-1}\right)\end{array}$ & 0.922 & 2.080 & 0.744 & 0.912 \\
\hline$\left(\mathrm{g} \mathrm{mg}^{-1} \min ^{-1}\right)$ & $(6.11 \pm 0.77) 10^{-3}$ & $(5.27 \pm 0.26) 10^{-3}$ & $(9.40 \pm 0.70) 10^{-3}$ & $(10.53 \pm 0.75) 10^{-3}$ \\
\hline $\mathrm{R}^{2}$ & 0.999 & 0.999 & 0.999 & 0.999 \\
\hline
\end{tabular}

It is obvious that the regression coefficient values obtained by the pseudo-second-order model are higher for all metal cation than the ones from the pseudo-first-order model. Moreover, when it was applied the pseudo-second-order kinetics, the theoretical $\mathrm{q}_{\mathrm{e}}$ values are close to the experimental values, pointing out that this model fitted well with the experimental adsorption data for $\mathrm{Pb}(\mathrm{II}), \mathrm{Cu}(\mathrm{II}), \mathrm{Cd}(\mathrm{II})$, and $\mathrm{Zn}(\mathrm{II})$. The data summarized in Table 3 also shows that the hybrid material, $\mathbf{S i T F}_{5} \mathbf{P P}$, has a high selectivity towards $\mathrm{Pb}$ (II) in terms of mass quantity. In this study, we decided to adopt mass quantity and not molar quantity, since we believe that it is more traceable and facilitates the comparison with other literature studies.

\subsubsection{Thermodynamic Studies}

The energy variation associated with the removal of $\mathrm{Pb}(\mathrm{II}), \mathrm{Cu}(\mathrm{II}), \mathrm{Cd}(\mathrm{II})$, and $\mathrm{Zn}$ (II) by $\mathbf{S i T F}_{5} \mathbf{P P}$, can be determined by thermodynamic parameters $[63,74-77]$, such as standard free energy $\left(\Delta \mathrm{G}^{\circ}\right.$; $\left.\mathrm{kJ} \mathrm{mol}{ }^{-1}\right)$, enthalpy $\left(\Delta \mathrm{H}^{\circ} ; \mathrm{kJ} \mathrm{mol}^{-1}\right)$, and entropy $\left(\Delta \mathrm{S}^{\circ} ; \mathrm{kJ} \mathrm{mol}^{-1} \mathrm{~K}^{-1}\right)$. These parameters were studied by carrying out the adsorption experiments between $299.15 \mathrm{~K}$ and $319.15 \mathrm{~K}$ at the optimum concentration (187.36 ppm) for each metal ion (Figure 7), and using the following equations [73]:

$$
\begin{aligned}
& \mathrm{K}_{\mathrm{d}}=\frac{\mathrm{C}_{0}-\mathrm{C}_{\mathrm{e}}}{\mathrm{C}_{\mathrm{e}}} \frac{\mathrm{V}}{\mathrm{m}} \\
& \ln \mathrm{K}_{\mathrm{d}}=\frac{\Delta \mathrm{S}^{\circ}}{\mathrm{T}}-\frac{\Delta \mathrm{H}^{\circ}}{\mathrm{RT}} \\
& \Delta \mathrm{G}^{\circ}=\Delta \mathrm{H}^{\circ}-\mathrm{T} \Delta \mathrm{S}^{\circ}
\end{aligned}
$$

where $C_{0}\left(\mathrm{mg} \mathrm{L}^{-1}\right)$ is the initial concentration of metal solution, $\mathrm{C}_{\mathrm{e}}\left(\mathrm{mg} \mathrm{L}^{-1}\right)$ is the equilibrium concentration, $\mathrm{V}(\mathrm{mL})$ is the volume of solution, $\mathrm{m}(\mathrm{g})$ is the dosage of sorbents, $\mathrm{R}$ is the universal gas constant $\left(8.314 \mathrm{~J} \mathrm{~mol}^{-1} \mathrm{~K}^{-1}\right)$ and $\mathrm{T}(\mathrm{K})$ is the absolute temperature. 


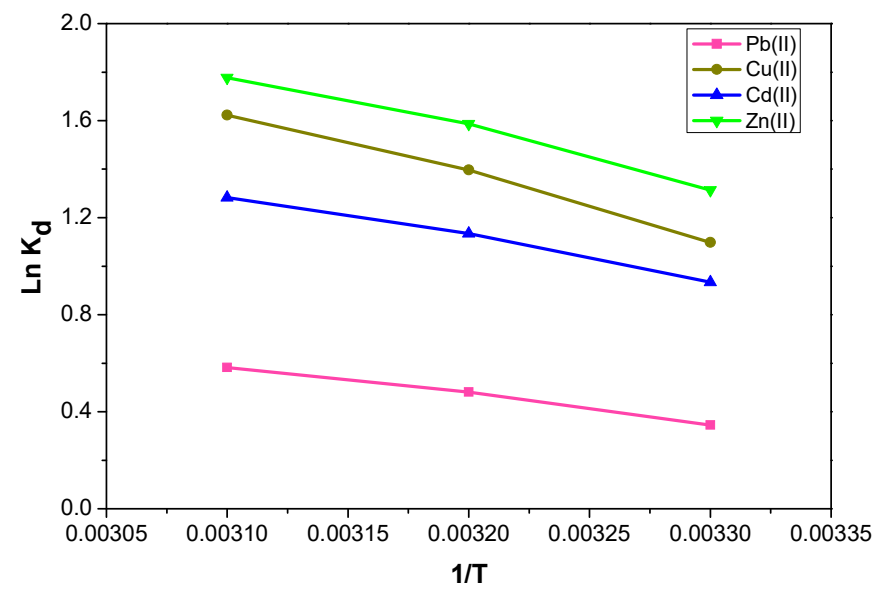

Figure 7. Effect of temperature for the sorption of metal ions onto SiTF $_{5} \mathbf{P P}$ (contact time: $30 \mathrm{~min}$; Adsorption dose: $\mathrm{V}=10 \mathrm{~mL}, \mathrm{~m}=10 \mathrm{mg}$ of $\mathbf{S i T F}_{5} \mathbf{P P}$ using optimum $\mathrm{pH}(\mathrm{pH}=6)$, optimum concentration (187.36 ppm in each case), and $25^{\circ} \mathrm{C}$. Lines just combine the points.

The $\Delta \mathrm{H}^{\circ}, \Delta \mathrm{S}^{\circ}$, and $\Delta \mathrm{G}^{\circ}$ values were calculated from the slope and intercept of $\ln \mathrm{K}_{\mathrm{d}}$ versus $1 / \mathrm{T}$ using the equations 5,6 , and 7 , respectively and are summarized in Table 4 . The $\Delta \mathrm{H}^{\circ}$ positive values showed that the adsorption is an endothermic process. The $\Delta \mathrm{S}^{\circ}$ positive values indicate an increase in randomness at solid-solution interface during the adsorption. The $\Delta \mathrm{G}^{\circ}$ negative values at all the studied temperatures indicate the spontaneous nature of the adsorption process for the four metal cations by the hybrid material $\mathbf{S i T F}_{5} \mathbf{P P}$ [74].

Table 4. Adsorption isotherm parameters of metal ions onto $\mathrm{SiTF}_{5} \mathbf{P P}$.

\begin{tabular}{|c|c|c|c|c|}
\hline Metal & $\Delta \mathrm{H}^{\circ}\left(\mathrm{kJ} \mathrm{mol}^{-1}\right)$ & $\Delta \mathrm{S}^{\circ}\left(\mathrm{J} \mathrm{K}^{-1} \mathrm{~mol}^{-1}\right)$ & $\mathrm{T}(\mathrm{K}) \pm 1 \mathrm{~K}$ & $\Delta \mathrm{G}^{\circ}\left(\mathrm{kJ} \mathrm{mol}^{-1}\right)$ \\
\hline $\mathrm{Pb}(\mathrm{II})$ & $9.883 \pm 0.100$ & $35.52 \pm 0.321$ & $\begin{array}{l}299.15 \\
309.15 \\
319.15\end{array}$ & $\begin{array}{l}-0.742 \\
-1.098 \\
-1.453\end{array}$ \\
\hline $\mathrm{Cu}(\mathrm{II})$ & $21.834 \pm 0.206$ & $81.26 \pm 0.659$ & $\begin{array}{l}299.15 \\
309.15 \\
319.15\end{array}$ & $\begin{array}{l}-2.477 \\
-3.290 \\
-4.103\end{array}$ \\
\hline $\mathrm{Cd}(\mathrm{II})$ & $14.485 \pm 0.149$ & $55.63 \pm 0.477$ & $\begin{array}{l}299.15 \\
309.15 \\
319.15\end{array}$ & $\begin{array}{l}-2.158 \\
-2.714 \\
-3.271\end{array}$ \\
\hline $\mathrm{Zn}(\mathrm{II})$ & $19.275 \pm 0.237$ & $74.50 \pm 0.759$ & $\begin{array}{l}299.15 \\
309.15 \\
319.15\end{array}$ & $\begin{array}{l}-3.010 \\
-3.756 \\
-4.500\end{array}$ \\
\hline
\end{tabular}

\subsubsection{Adsorption Isotherms}

The adsorption isotherms were determined by varying the initial concentration of metal cations from 10 to $300 \mathrm{mg} \mathrm{L}^{-1}$ with $10 \mathrm{mg}$ of $\operatorname{SiTF}_{5} \mathbf{P P}$ at $25^{\circ} \mathrm{C}$ and $\mathrm{pH} 6$ (Figure 8). 


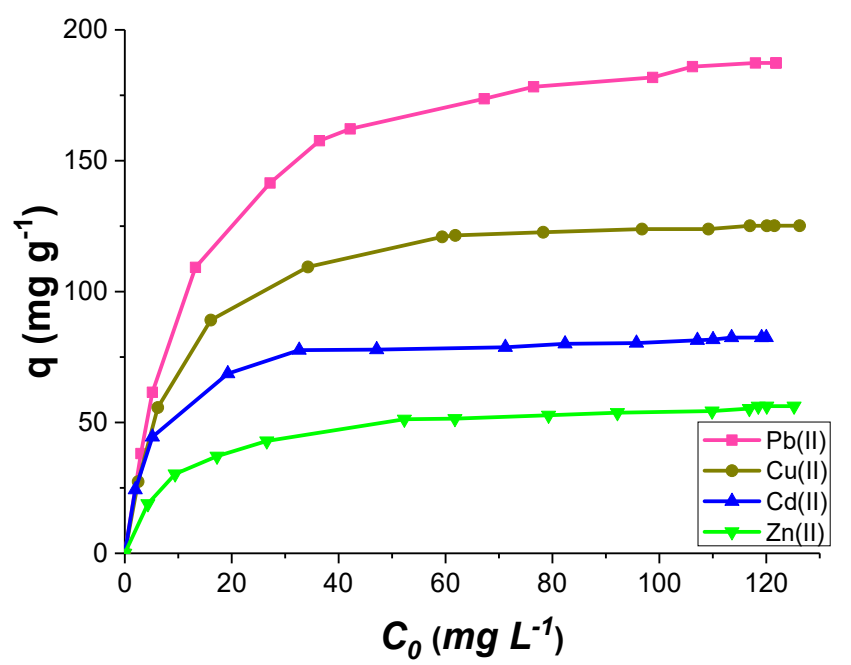

Figure 8. Effect of concentration on metal ions adsorption onto $\mathbf{S i T F}_{5} \mathbf{P P}$ (Adsorption dose: $10 \mathrm{mg}$; $\mathrm{V}=10 \mathrm{~mL} ; \mathrm{T}=25^{\circ} \mathrm{C}$; and $\left.\mathrm{pH}=6\right)$. Lines just combine the points.

The curves of the graph show that the adsorption increases with the increase of the concentration of metal cations and reaches steady state values. The experimental data for each metal ion were fitted into both the Langmuir and the Freundlich isotherm model. The first model describes the monolayer sorption of metal ions on the surface of the sorbent, while the second one describes both multi-layer sorption and sorption on heterogeneous surfaces. The nonlinearized experimental data from the Langmuir isotherm (eqn. 6) and from the Freundlich isotherm (eqn. 7) are expressed as follows [70,78].

$$
\begin{gathered}
\mathrm{q}_{\mathrm{e}}=\frac{\mathrm{qK}_{\mathrm{L}} \mathrm{C}_{\mathrm{e}}}{1+\mathrm{K}_{\mathrm{L}} \mathrm{C}_{\mathrm{e}}} \\
\mathrm{q}_{\mathrm{e}}=\mathrm{K}_{\mathrm{F}} \mathrm{C}_{\mathrm{e}}^{1 / \mathrm{n}}
\end{gathered}
$$

where $\mathrm{q}_{\mathrm{e}}$ is the amount of analyte sorbed $\left(\mathrm{mg} \mathrm{g}^{-1}\right)$, $\mathrm{q}$ is the saturated adsorption capacity $\left(\mathrm{mg} \mathrm{g}^{-1}\right), \mathrm{K}_{\mathrm{L}}$ is the Langmuir adsorption constant $\left(\mathrm{L} \mathrm{mg}^{-1}\right), \mathrm{C}_{\mathrm{e}}$ is the equilibrium ion concentration in the solution $\left(\mathrm{mg} \mathrm{L}^{-1}\right) ; \mathrm{K}_{\mathrm{F}}$ is the binding energy constant $\left(\mathrm{mg} \mathrm{g}^{-1}\right)$ and $\mathrm{n}$ is Freundlich constant. The fitted curves of nonlinear Langmuir and Freundlich models are given in Figure 9. The Langmuir and Freundlich isotherm parameters for adsorption of $\mathrm{Pb}(\mathrm{II}), \mathrm{Cu}(\mathrm{II}), \mathrm{Cd}(\mathrm{II})$ and $\mathrm{Zn}$ (II) are summarized in Table 5. The results show that the Langmuir isotherm fitted quite well with the experimental data $\left(R^{2} \geq 0.998\right)$, indicating a uniform solid surface on the sorbent, and a regular monolayer sorption. 


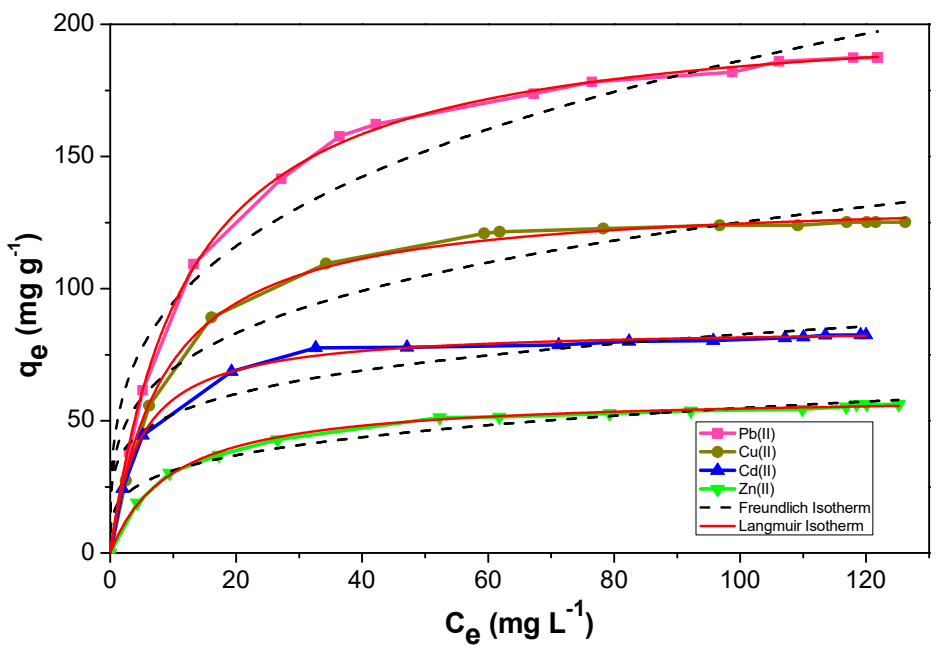

Figure 9. Langmuir and Freundlich adsorption models fits of $\mathrm{Pb}(\mathrm{II}), \mathrm{Cu}(\mathrm{II}), \mathrm{Cd}(\mathrm{II})$ and $\mathrm{Zn}$ (II) on SiTF5PP.

Table 5. Adsorption isotherm parameters of metal cations onto $\mathrm{SiTF}_{5} \mathbf{P P}$.

\begin{tabular}{|c|c|c|c|c|c|c|c|}
\hline \multirow{2}{*}{ Metal } & \multicolumn{4}{|c|}{ Langmuir Isotherm Model } & \multicolumn{3}{|c|}{ Freundlich Isotherm Model } \\
\hline & $q\left(\mathrm{mg} \mathrm{g}^{-1}\right)$ & $q\left(\mathrm{mmol} \mathrm{g}^{-1}\right)$ & $K_{L}\left(L_{m g}{ }^{-1}\right)$ & $\mathbf{R}^{2}$ & $K_{F}\left(m g g^{-1}\right)$ & $\mathbf{N}$ & $\mathbf{R}^{2}$ \\
\hline $\mathrm{Pb}(\mathrm{II})$ & $206.282 \pm 0.992$ & 0.995 & $0.082 \pm 0.001$ & 0.999 & $48.209 \pm 6.486$ & $3.407 \pm 0.383$ & 0.952 \\
\hline $\mathrm{Cu}(\mathrm{II})$ & $135.374 \pm 0.880$ & 2.131 & $0.115 \pm 0.004$ & 0.998 & $38.920 \pm 5.789$ & $3.945 \pm 0.529$ & 0.944 \\
\hline $\mathrm{Cd}(\mathrm{II})$ & $85.384 \pm 0.444$ & 0.759 & $0.212 \pm 0.008$ & 0.998 & $33.282 \pm 4.043$ & $5.060 \pm 0.723$ & 0.944 \\
\hline $\mathrm{Zn}(\mathrm{II})$ & $59.997 \pm 0.400$ & 0.917 & $0.101 \pm 0.003$ & 0.998 & $17.724 \pm 1.637$ & $4.080 \pm 0.354$ & 0.974 \\
\hline
\end{tabular}

\subsubsection{Selectivity of $\mathrm{SiTF}_{5} \mathrm{PP}$}

The selectivity of $\mathbf{S i T F}_{5} \mathbf{P P}$ towards $\mathrm{Pb}(\mathrm{II})$, using a mixture containing all the metal ions (Cd(II), $\mathrm{Cu}(\mathrm{II}), \mathrm{Zn}(\mathrm{II})$, and $\mathrm{Pb}(\mathrm{II}) ; 187.36 \mathrm{ppm}$ of each), was performed through a batch method, and aqueous solutions. The results are summarized in Figure 10. Although the extraction capacity seems to decrease when compared to the value obtained in the absence of extra metal cations, the outstanding selectivity observed for $\mathrm{Pb}$ (II) suggests that the porphyrin-silica-based hybrid $\mathbf{S i T F}_{5} \mathbf{P P}$ is a promising adsorbent, with high potential to be used to remove $\mathrm{Pb}(\mathrm{II})$ from aqueous solutions, containing competing ions.

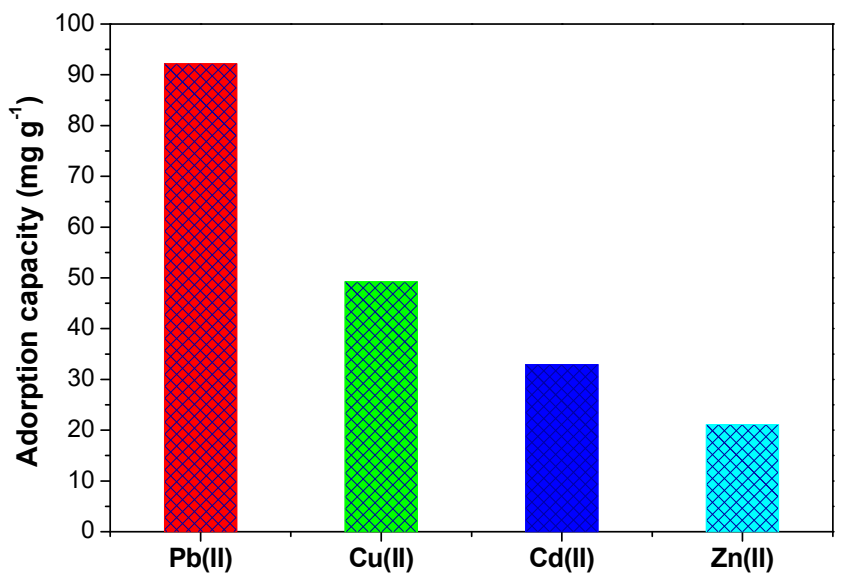

Figure 10. Effect of foreign metal ions on the extraction of $\mathrm{Pb}(\mathrm{II})$ with $\mathrm{SiTF}_{5} \mathbf{P P}$ (contact time: $25 \mathrm{~min}$, $\mathrm{pH}=6, \mathrm{~T}=25^{\circ} \mathrm{C}$. Adsorption dose: $\mathrm{V}=10 \mathrm{~mL}, \mathrm{~m}=10 \mathrm{mg}$ of $\mathbf{S i T F}_{5} \mathbf{P P}$ at optimum concentrations: 187.36 ppm of each studied metal, $\mathrm{Pb}(\mathrm{II}), \mathrm{Cu}(\mathrm{II}), \mathrm{Cd}(\mathrm{II})$, and $\mathrm{Zn}(\mathrm{II})$. 
2.2.6. Applicability of $\mathrm{SiTF}_{5} \mathrm{PP}$ for the Removal Potentially Toxic Transition Metals from Real Samples

The applicability of $\mathbf{S i T F}_{5} \mathbf{P P}$ for the removal of $\mathrm{Pb}(\mathrm{II}), \mathrm{Cu}(\mathrm{II}), \mathrm{Cd}(\mathrm{II})$, and $\mathrm{Zn}(\mathrm{II})$ was evaluated in real conditions using natural water samples from Moulouya River (Morocco). All the samples after being collected with a polyethylene bottle, were filtered using a nylon membrane $(0.45 \mathrm{~mm})$ and were analyzed without storage. The assays were performed by mixing $10 \mathrm{mg}$ of the adsorbent, $10 \mathrm{~mL}$ of the water sample, and $0.065 \mathrm{~mL}$ of $4.5 \times 10^{-3} \% \mathrm{HNO}_{3}$ at $25^{\circ} \mathrm{C}$. The metal cations concentrations were determined by flame atomic absorption spectrometry (FAAS). All the experiments that were done in duplicate and are summarized in Table 6.

Table 6. Extraction of potential toxic metal cations in natural real water samples.

\begin{tabular}{cccc}
\hline Water Samples & Metal Ion & $\begin{array}{c}\mathbf{C}_{\text {found }} \pm \mathbf{0 . 0 5} \\
\left(\mathbf{m g ~ L}^{-1}\right)\end{array}$ & $\begin{array}{c}\text { Metal Ions Concentration after } \\
\text { Adsorption on SiTF }_{\mathbf{5}} \mathbf{P P} \mathbf{~ ( m g ~ g ~}^{\mathbf{1}} \mathbf{)}\end{array}$ \\
\hline \multirow{3}{*}{ Moulouya River } & $\mathrm{Pb}(\mathrm{II})$ & 0.7506 & 0.6199 \\
& $\mathrm{Cd}(\mathrm{II})$ & 0.3133 & 0.2048 \\
& $\mathrm{Cu}(\mathrm{II})$ & 0.9794 & 0.1726 \\
\hline
\end{tabular}

\footnotetext{
$\mathrm{C}_{\mathrm{found}}$ is the initial metal contents in river water determined by atomic absorption measurements.
}

For the other quality parameters of river water sample that can affect the adsorption process study, we measured the amount of several anions and cations, namely, $\mathrm{Na}^{+}, \mathrm{Ca}^{2+}, \mathrm{K}^{+}, \mathrm{Mg}^{2+}, \mathrm{NH}_{4}{ }^{+}$, $\mathrm{SO}_{4}{ }^{2-}, \mathrm{NO}_{3}{ }^{-}, \mathrm{HCO}_{3}{ }^{-}, \mathrm{PO}_{4}{ }^{3-}$ and the total organic carbon (TOC), in real water samples (see Table $\mathrm{S} 2$ in ESI). The results showed that under the optimum conditions established before, the presence of other ions in solution does not significantly interfere in the absorption process of the studied metal cations [Pb(II), Cu(II), Cd(II) and $\mathrm{Zn}(\mathrm{II})]$. Therefore, the used method is suitable for analysis of real watercourse samples with complex matrixes, allowing a good affinity for $\mathrm{Pb}$ (II), $\mathrm{Cu}$ (II) and $\mathrm{Cd}$ (II) ions as demonstrated in this study. It is worth to refer that the presence of other ions, that naturally exist in real waters samples, present no interferences in the extraction and determination of $\mathrm{Pb}(\mathrm{II})$.

\subsubsection{Regeneration Ability of $\mathrm{SiTF}_{5} \mathrm{PP}$}

The new hybrid $\mathbf{S i T F}_{5} \mathbf{P P}$ can be easily regenerated just by washing with an acidic solution for a few minutes (6 M HCl of 5-10 mL). Indeed, after five cycles of adsorbent regeneration, no significant change in the adsorption capacity was observed (data not shown). The stability of the organic groups into the solid surface was also confirmed by TGA, with no significant alterations in the sorbent material after five utilization cycles (Figure 11).

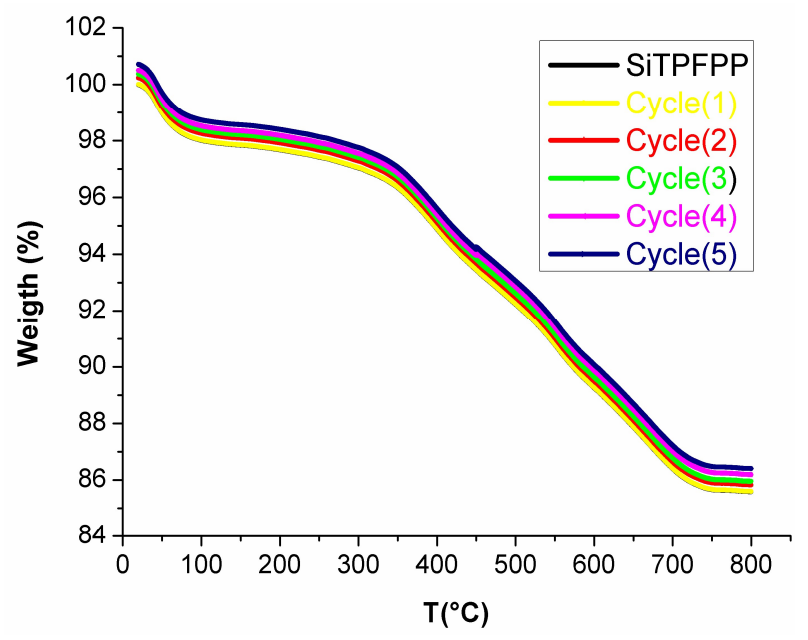

Figure 11. Thermogravimetric curves after five cycles of adsorbent regeneration and the curve before regeneration of $\mathbf{S i T F}_{5} \mathbf{P P}$. 


\subsubsection{Comparison with Alternative Adsorbents}

In Table 7 is summarized the adsorption capacity of other silica gel based adsorbents reported in the literature towards $\mathrm{Pb}$ (II) and the other metals. It is evident that the hybrid,, described in this work presents a higher adsorption capacity in terms of mass quantity towards $\mathrm{Pb}(\mathrm{II})$, when compared with others systems that have been recently reported in the literature and bearing a porphyrinic and non-porphyrinic ligands. The results in Table 7 also show that the new silica-based adsorbent functionalized with a porphyrin unit prepared in this work, has a remarkable adsorption ability for $\mathrm{Cu}(\mathrm{II})$ ion.

Table 7. Comparison of $\mathrm{SiTF}_{5} \mathbf{P P}$ performances with some recently reported sorbents for $\mathrm{Pb}(\mathrm{II})$ adsorption.

\begin{tabular}{|c|c|c|c|c|c|}
\hline \multirow{2}{*}{ Silica gel-Ligand } & \multirow{2}{*}{ Ref } & \multicolumn{4}{|c|}{ Adsorption Capacity $\left(\mathrm{mg} \mathrm{g}^{-1}\right)$} \\
\hline & & $\mathrm{Pb}(\mathrm{II})$ & $\mathrm{Cu}(\mathrm{II})$ & Cd(II) & $\mathrm{Zn}(\mathrm{II})$ \\
\hline 5,10,15,20-Tetrakis(pentafluorophenyl)porphyrin & This work & 187.36 & 125.17 & 82.45 & 56.23 \\
\hline $5,10,15,20$-Tetraphenylporphyrin & [68] & 55.17 & 19.08 & 26.46 & 34.62 \\
\hline$N, N$-bipyrazole amine & [25] & 123 & - & - & - \\
\hline Glutaraldehyde & [79] & 29.32 & - & - & - \\
\hline 2-Hydroxy-3-methoxybenzaldehyde & [80] & 2.27 & 4.70 & - & - \\
\hline Bipyridine tripodal receptor & [81] & 99.68 & 64.84 & 42.18 & 82.68 \\
\hline Nitrothiophene & [82] & 52.41 & 61.52 & 38.45 & 35.72 \\
\hline PMAEEDA & [83] & 61.90 & 19.96 & 19.34 & 17.16 \\
\hline Ketoenol Furane & [84] & 18.75 & 32.08 & 52.15 & 23.36 \\
\hline$N$-[3(Trimethoxysilyl)propyl]ethyl-ene-diamine & [85] & 96.43 & 27.22 & - & 12.16 \\
\hline 3-(2-Aminoethylamino)pro-pyldimethoxymethylsilane & [86] & 100.58 & 74.69 & 121.43 & - \\
\hline $\mathrm{SiO}_{2}-\mathrm{g}-\mathrm{GMA} / \beta-\mathrm{CD}-\mathrm{Ac}$ & [87] & 51.02 & 110.0 & 15.20 & - \\
\hline Pentane-1,2-dicarboxylic acid & [88] & 122.0 & 38.0 & 30.0 & 28.0 \\
\hline (E)-4-((Pyridin-2-yl-methyl-ene)amino)phenol & [29] & 36.38 & - & 32.38 & 92.00 \\
\hline Dithiocarbamate & [89] & 42.16 & 25.00 & 10.01 & 26.01 \\
\hline Cetyltrimethylammonium bromide & [90] & - & 32.20 & 8.00 & - \\
\hline Nano-sized $\mathrm{Fe}_{3} \mathrm{O}_{4}$ & [91] & 166.67 & 37.04 & - & - \\
\hline MCM-41/N-(3-trimethoxysilyl)-propyl) diethylenetriamine & [92] & 77.52 & - & - & - \\
\hline (2Z)-1-(1,5-dimethyl-1H-pyrazol-3-yl)-3-hydroxybut-2-en-1-one & [93] & 94.18 & 71.40 & 40.18 & 83.33 \\
\hline
\end{tabular}

\section{Materials and Methods}

\subsection{General Remarks}

All solvents and other chemicals (Aldrich, Steinheim, Germany, purity $>99.5 \%$ ) were of analytical grade and used without further purification. Silica gel (Merck, Darmstadt, Germany; 70-230 mesh, $60 \AA$ ), was activated before use at $120{ }^{\circ} \mathrm{C}$ for $24 \mathrm{~h}$. The 3-aminopropyltrimethoxysilane (Janssen Chemicals, Beerse, Belgium) was used without purification. The silica particles were characterized on a scanning transmission electron microscope (SEM) Hitachi S4100 (Hitachi, Krefeld, Germany), equipped with an energy dispersive spectrometer operating at $30 \mathrm{kV}$ and a Jeol JEM-2200FS (JEOL, Tokyo, Japan) transmission electron microscope (TEM) operating at $200 \mathrm{kV}$. A Micromeritics Gemini 2380 surface area analyzer with $c a .50 \mathrm{mg}$ weight was used to perform the Brunauer-Emmett-Teller (BET)/Barrett-Joyner-Halenda (BJH) determination of specific surface area and pore size distribution. The ${ }^{13} \mathrm{C}$ solid-state CPMAS NMR spectroscopy experiments were recorded on a Bruker Avance III 400 spectrometer (Wissembourg, France) at room temperature, using a double-resonance $4 \mathrm{~mm}$ Bruker MAS probe and a spinning rate of $12 \mathrm{kHz}$. The ${ }^{13} \mathrm{C}$ Larmor frequency was $100.6 \mathrm{MHz}$. Elemental analyses (EA) were performed on a LECO CHNS-932 apparatus (LECO Corporation, MI, USA). Attenuated Total Reflectance Transmission Fourier Transform Infrared (ATR-FTIR) spectra were recorded on a FT Mattson 7000 galaxy series spectrophotometer (Mattson Instruments, WI, USA). Solid UV-Vis absorption spectra in the spectral range 350-800 $\mathrm{nm}$ were registered using a JASCO V-560 spectrophotometer (JASCO International Co., Ltd., Tokyo, Japan). For the X-ray diffraction (XRD) measurements, self-oriented solids were placed on neutral glass sample holders. The measurements were done in the reflection mode using X'Pert MPD Philips diffractometer (Cu K $\alpha 1,2$ 
X-radiation, $\lambda_{1}=1.540598 \AA$ and $\lambda_{2}=1.544426 \AA$, (Malvern, Gondomar, Portugal), equipped with an $X^{\prime}$ Celerator detector and a flat plate sample holder in a Bragg-Brentano para-focusing optics configuration $(40 \mathrm{kV}, 50 \mathrm{~mA})$. Intensity data were collected by the step counting method (step 0.02), in continuous mode. The nitrogen adsorption-desorption was obtained using a Thermoquest Sorpsomatic 1990 analyzer (Micromeritics Headquarters, GA, USA). The mass loss assays were performed in 90:10 oxygen/nitrogen atmospheres on a TGA Q50 V6.7 Build 203 instrument (Shimatzu, Kyoto, Japan), at a heating rate of $10{ }^{\circ} \mathrm{C} \mathrm{min}^{-1}$. The metal ions determination was performed by atomic absorption measurements, using a Spectra Varian A.A. 400 spectrophotometer (COSTE, Oujda, Morocco), equipped with an air-acetylene flame. The wavelength used for monitoring the transitions metals $\mathrm{Pb}(\mathrm{II}), \mathrm{Cu}(\mathrm{II}), \mathrm{Cd}(\mathrm{II}$,$) and \mathrm{Zn}(\mathrm{II})$ is $283.3,324.8,228.8$ and $213.9 \mathrm{~nm}$, respectively. Metal cations detection is in the range: 1-12 ppm, for $\mathrm{Pb}, 1-4 \mathrm{ppm}$ for $\mathrm{Cu}$, and 0.1-0.6 ppm for $\mathrm{Cd}$, and $\mathrm{Zn}$, respectively. The calibration curve method was used to elucidate the results of measurements.

\subsection{Preparation of 3-Aminopropylsilica (SiPn)}

A dispersion of activated silica gel $(30 \mathrm{~g})$ in dry toluene $(200 \mathrm{~mL})$ was refluxed and mechanically stirred under a nitrogen atmosphere for $2 \mathrm{~h}$. Then, under continuous stirring, it was added 3-aminopropyltrimethoxysilane (13 mL) gradually and the mixture was refluxed for $24 \mathrm{~h}$. The resulting solid was filtered washed with toluene and ethanol and Soxhlet extracted with a mixture of ethanol and dichloromethane $(1 / 1)$ for $12 \mathrm{~h}$, to remove the silylating reagent residue $[81,94]$. The functionalized silica gel, named SiPn, was dried at room temperature for $1 \mathrm{~h}$ under vacuum and characterized by elemental analysis. Elemental analyses: $\% \mathrm{C}=5.03 ; \% \mathrm{~N}=1.63$.

\subsection{Synthesis of Porphyrin-Substituted Silica $\left(S_{i T F} P P\right)$}

A mixture containing SiPn (4 g) and $150 \mathrm{mg}$ of 5,10,15,20-tetrakis(pentafluorophenyl)porphyrin $\mathbf{H}_{2} \mathbf{T F}_{5} \mathbf{P P}$ in $30 \mathrm{~mL}$ of dry toluene was maintained under reflux for $48 \mathrm{~h}$. Then, the resulting solid was filtered, dried and Soxhlet extracted with toluene, methanol and dichloromethane for $12 \mathrm{~h}$. The product named $\mathbf{S i T F}_{5} \mathbf{P P}$ was then dried at $40{ }^{\circ} \mathrm{C}$ for $4 \mathrm{~h}$ under vacuum. Elemental analyses: $\% \mathrm{C}=8.00$; $\% \mathrm{~N}=1.53$.

\subsection{Metal Cation Adsorption Experiments}

The experiments to evaluate the metal adsorption ability of the synthesized hybrid material towards $\mathrm{Pb}(\mathrm{II}), \mathrm{Cu}(\mathrm{II}), \mathrm{Cd}(\mathrm{II})$, and $\mathrm{Zn}(\mathrm{II})$ were performed at $25^{\circ} \mathrm{C}$ by stirring $10 \mathrm{mg}$ of $\mathbf{S i T F}_{5} \mathbf{P P}$, with $10 \mathrm{~mL}$ of an aqueous solution containing a single-metal at the optimum concentration of $187.36 \mathrm{ppm}$. The $\mathrm{pH}$ of the solution was adjusted using $0.1 \mathrm{M} \mathrm{HCl}$ and $0.1 \mathrm{M} \mathrm{NaOH}$ solutions. After shaking for 1 $\mathrm{h}$, the adsorbent-solution mixtures were filtered to collect the final solutions. The initial and final metal concentrations (before and after the presence of the adsorbent material $\mathbf{S i T F}_{5} \mathbf{P P}$ ) were determined by the flame atomic absorption spectrometry (FAAS). The amount of metal ions adsorbed by $\mathbf{S i T F}_{5} \mathbf{P P}$ from aqueous solution was calculated using the following equations [95]:

$$
\begin{gathered}
\mathrm{Q}_{\mathrm{M}}=\left(\mathrm{C}_{0}-\mathrm{C}_{\mathrm{e}}\right) \times \mathrm{V} / \mathrm{W} \\
\mathrm{Q}_{\mathrm{W}}=\mathrm{Q}_{\mathrm{M}} \times \mathrm{M}
\end{gathered}
$$

where $Q_{M}$ is the amount of the metal ion on the adsorbent $\left(\mathrm{mmol} \mathrm{g}^{-1}\right), Q_{W}$ is the amount of the metal ion on the adsorbent $\left(\mathrm{mg} \mathrm{g}^{-1}\right), \mathrm{V}$ is the volume of the aqueous solution $(\mathrm{L}), \mathrm{W}$ is the weight of the adsorbent $(\mathrm{g}), \mathrm{C}_{0}$ is the initial concentration of metal ion $\left(\mathrm{mmol} \mathrm{L}^{-1}\right), \mathrm{C}_{\mathrm{e}}$ is the equilibrium metal ion concentration in solution $\left(\mathrm{mmol} \mathrm{L}^{-1}\right)$, and $\mathrm{M}$ the atomic weight of the metal $\left(\mathrm{g} \mathrm{mol}^{-1}\right)$. 


\subsection{Batch Experiments}

The applicability of $\mathbf{S i T F}_{5} \mathbf{P P}$ for the removal of transition metals [Pb(II), Cu(II), Cd(II), and Zn(II)]) was determined by adding $10 \mathrm{mg}$ of the adsorbent to an aqueous solution of each metal ion $(10 \mathrm{~mL})$ at different concentrations (10 to $300 \mathrm{mg} \mathrm{L}^{-1}$ ) at $25^{\circ} \mathrm{C}$. The $\mathrm{pH}$ effect was studied in the range of $1-7$. The effect of contact time and kinetic modelling were also determined at room temperature for 5-30 min. After a pre-established contact time, the mixture was then filtered and the unextracted metal ion present in the filtrate (supernatant) was determined using a flame atomic absorption spectrometer (FAAS). Analyses were performed in duplicate for each sample, and the mean data were reported.

\section{Conclusions}

In summary, this work allowed the development and characterization of an efficient inorganic-organic hybrid material for metal sorption, based on the heterogenization of 5,10,15,20-tetrakis(pentafluorophenyl)porphyrin $\mathbf{H}_{2} \mathbf{T} \mathbf{F}_{5} \mathbf{P P}$ on a chemically modified silica.

The study shows that metal cations adsorption is more efficient at $\mathrm{pH}$ in the range 5 to 7 , and the maximum adsorption is reached in only $25 \mathrm{~min}$, suggesting a fast-external diffusion and surface adsorption. The hybrid $\mathbf{S i T F}_{\mathbf{5}} \mathbf{P P}$ is particularly efficient towards $\mathrm{Pb}$ (II) with a maximum absorption value of $187.36 \mathrm{mg} \mathrm{g}^{-1}$, while for the others metal cations studied were obtained values in the range $125.17-56.23 \mathrm{mg} \mathrm{g}^{-1}$. Its efficiency can be attributed to the presence of fluorine atoms on the meso phenyl rings of the porphyrinic macrocycle, which increase the electron density of the nitrogen in the core.

The adsorption kinetics fit into the pseudo-second-order model, showing homogeneous characteristics. The comparison of different isotherm models indicated that the Langmuir model gave the best fit to the experimental data, and the increase of the metal cations adsorption ability with the temperature, indicates that this is an endothermic and spontaneous process.

The hybrid prepared displays an excellent adsorption ability towards $\mathrm{Pb}(\mathrm{II})$ and $\mathrm{Cu}(\mathrm{II})$, when compared with other adsorbents described in the literature, and showed a high performance in a competitive mode and in real water samples. Moreover, it can be regenerated several times (at least 5 times) without the loss of their adsorption capability, suggesting that an efficient and low-cost adsorbent for metal cations removal from aqueous solutions.

Supplementary Materials: The following are available online, Table S1: Elemental analysis, Figure S1: ATR-FTIR Spectra of free silica (Si), 3-aminopropylsilica (SiPn) and SiTF 5 PP, Figure S2: ${ }^{13}$ C NMR spectra of SiPn (top) $\mathbf{S i T F}_{5} \mathbf{P P}$ (bottom), Figure S3: X - ray diffraction spectra of free silica (Si), 3-aminopropyl-silica (SiPn) and $\mathbf{S i T F} \mathbf{P P}_{5}$, Figure S4: Electronic density for NTPP and $\mathbf{H}_{2}\left(\mathbf{T F}_{5} \mathbf{P P}\right)$ determinate with Marvin 6.1.6. Software.

Author Contributions: Investigation, C.E.A. and N.M.M.M.; supervision, S.R. and M.G.P.M.S.N.; validation, S.R., M.A.F.F., M.G.P.M.S.N., and N.M.M.M.; writing - original draft, S.R. and N.M.M.M.; writing - review and editing, M.A.F.F., M.G.P.M.S.N., and N.M.M.M.

Funding: The authors extend their appreciation to the PPR2-MESRSFC-CNRST-P10 project (Morocco) for the financial support. We are grateful to the University of Aveiro and FCT/MCT for its financial support for the QOPNA (Química Orgânica, Produtos Naturais e Agroalimentares) research Unit (FCT UID/QUI/00062/2019) through national funds and, where applicable, co-financed by the FEDER, within the PT2020 Partnership Agreement, and to the Portuguese NMR Network. Nuno M. M. Moura is grateful to FCT for his research contract (REF.-048-88-ARH/2018).

Conflicts of Interest: The authors declare no conflict of interest.

\section{References}

1. Bernard, A. Cadmium and its adverse effects on human health. Indian J. Med. Res. 2008, 128, 557. [PubMed]

2. Hajdu, I.; Bodnár, M.; Csikós, Z.; Wei, S.; Daróczi, L.; Kovács, B.; Győri, Z.; Tamás, J.; Borbély, J. Combined nano-membrane technology for removal of lead ions. J. Memb. Sci. 2012, 409, 44-53. [CrossRef]

3. Liang, X.-X.; Wang, N.; Qu, Y.-L.; Yang, L.-Y.; Wang, Y.-G.; Ouyang, X.-K. Facile Preparation of Metal-Organic Framework (MIL-125)/Chitosan Beads for Adsorption of Pb(II) from Aqueous Solutions. Molecules 2018, 23, 1524. [CrossRef] [PubMed] 
4. Kumar, R.; Kumar, M.; Ahmad, R.; Barakat, M. 1-Methionine modified Dowex-50 ion-exchanger of reduced size for the separation and removal of $\mathrm{Cu}$ (II) and $\mathrm{Ni}$ (II) from aqueous solution. Chem. Eng. J. 2013, 218, 32-38. [CrossRef]

5. Dolgormaa, A.; Lv, C.-j.; Li, Y.; Yang, J.; Yang, J.-X.; Chen, P.; Wang, H.-p.; Huang, J. Adsorption of Cu(II) and $\mathrm{Zn}$ (II) Ions from Aqueous Solution by Gel/PVA-Modified Super-Paramagnetic Iron Oxide Nanoparticles. Molecules 2018, 23, 2982. [CrossRef] [PubMed]

6. Bahadir, T.; Bakan, G.; Altas, L.; Buyukgungor, H. The investigation of lead removal by biosorption: An application at storage battery industry wastewaters. Enzyme Microb. Technol. 2007, 41, 98-102. [CrossRef]

7. Mohsen-Nia, M.; Montazeri, P.; Modarress, $\mathrm{H}$. Removal of $\mathrm{Cu} 2+$ and $\mathrm{Ni2}+$ from wastewater with a chelating agent and reverse osmosis processes. Desalination 2007, 217, 276-281. [CrossRef]

8. Rubio, J.; Souza, M.; Smith, R. Overview of flotation as a wastewater treatment technique. Miner. Eng. 2002, 15, 139-155. [CrossRef]

9. Wu, Z.; He, M.; Guo, X.; Zhou, R. Removal of antimony (III) and antimony (V) from drinking water by ferric chloride coagulation: Competing ion effect and the mechanism analysis. Sep. Purif. Technol. 2010, 76, 184-190. [CrossRef]

10. Misra, R.; Jain, S.; Khatri, P. Iminodiacetic acid functionalized cation exchange resin for adsorptive removal of $\mathrm{Cr}$ (VI), Cd (II), Ni (II) and Pb (II) from their aqueous solutions. J. Hazard. Mater. 2011, 185, 1508-1512. [CrossRef]

11. $\mathrm{Ku}, \mathrm{Y}$; J Jung, I.-L. Photocatalytic reduction of $\mathrm{Cr}(\mathrm{VI})$ in aqueous solutions by UV irradiation with the presence of titanium dioxide. Water Res. 2001, 35, 135-142. [CrossRef]

12. Keng, P.-S.; Lee, S.-L.; Ha, S.-T.; Hung, Y.-T.; Ong, S.-T. Removal of hazardous heavy metals from aqueous environment by low-cost adsorption materials. Environ. Chem. Lett. 2014, 12, 15-25. [CrossRef]

13. Ngah, W.W.; Teong, L.; Hanafiah, M. Adsorption of dyes and heavy metal ions by chitosan composites: A review. Carbohydr. Polym. 2011, 83, 1446-1456. [CrossRef]

14. Afkhami, A.; Saber-Tehrani, M.; Bagheri, H. Simultaneous removal of heavy-metal ions in wastewater samples using nano-alumina modified with 2, 4-dinitrophenylhydrazine. J. Hazard. Mater. 2010, 181, 836-844. [CrossRef]

15. Ahn, C.K.; Park, D.; Woo, S.H.; Park, J.M. Removal of cationic heavy metal from aqueous solution by activated carbon impregnated with anionic surfactants. J. Hazard. Mater. 2009, 164, 1130-1136. [CrossRef]

16. Mohan, S.; Gandhimathi, R. Removal of heavy metal ions from municipal solid waste leachate using coal fly ash as an adsorbent. J. Hazard. Mater. 2009, 169, 351-359. [CrossRef]

17. Ahluwalia, S.S.; Goyal, D. Microbial and plant derived biomass for removal of heavy metals from wastewater. Bioresour. Technol. 2007, 98, 2243-2257. [CrossRef]

18. Lăcrămioara, (N.)N.; Bulgariu, L. Optimization of process parameters for heavy metals biosorption onto mustard waste biomass. Open Chem. 2016, 14, 175-187. [CrossRef]

19. Bulgariu, L.; Bulgariu, D. Functionalized soy waste biomass-A novel environmental-friendly biosorbent for the removal of heavy metals from aqueous solution. J. Clean. Prod. 2018, 197, 875-885. [CrossRef]

20. Perez-Quintanilla, D.; Del Hierro, I.; Fajardo, M.; Sierra, I. Mesoporous silica functionalized with 2-mercaptopyridine: Synthesis, characterization and employment for $\mathrm{Hg}$ (II) adsorption. Microporous Mesoporous Mater. 2006, 89, 58-68. [CrossRef]

21. Kooshki, M.; Shams, E. Selective response of dopamine in the presence of ascorbic acid on carbon paste electrode modified with titanium phosphated silica gel. Anal. Chim. Acta 2007, 587, 110-115. [CrossRef]

22. Mostafa, G.A.; Hassanien, M.M.; Abou-El-Sherbini, K.S.; GÖRLITZ, V. Controlled-pore silica glass modified with N-propylsalicylaldimine for the separation and preconcentration of trace $\mathrm{Al}$ (III), $\mathrm{Ag}$ (I) and $\mathrm{Hg}$ (II) in water samples. Anal. Sci. 2003, 19, 1151-1156. [CrossRef]

23. Camel, V. Solid phase extraction of trace elements. Spectrochim. Acta Part B 2003, 58, 1177-1233. [CrossRef]

24. Walcarius, A.; Mercier, L. Mesoporous organosilica adsorbents: Nanoengineered materials for removal of organic and inorganic pollutants. J. Mater. Chem. 2010, 20, 4478-4511. [CrossRef]

25. Radi, S.; Tighadouini, S.; Toubi, Y.; Bacquet, M. Polysiloxane surface modified with bipyrazolic tripodal receptor for quantitative lead adsorption. J. Hazard. Mater. 2011, 185, 494-501. [CrossRef]

26. Radi, S.; Tighadouini, S.; Bacquet, M.; Degoutin, S.; Cazier, F.; Zaghrioui, M.; Mabkhot, Y.N. Organically modified silica with pyrazole-3-carbaldehyde as a new sorbent for solid-liquid extraction of heavy metals. Molecules 2013, 19, 247-262. [CrossRef] 
27. Tighadouini, S.; Radi, S.; Bacquet, M.; Dacquin, J.-P.; Mabkhot, Y.N.; Jodeh, S.; Warad, I.; Zaghrioui, M. Synthesis of 1-(Furan-2-yl) imine functionalized silica as a chelating sorbent and its preliminary use in metal Ion adsorption. Sep. Sci. Technol. 2015, 50, 710-717. [CrossRef]

28. Radi, S.; Attayibat, A.; El-Massaoudi, M.; Bacquet, M.; Jodeh, S.; Warad, I.; Al-Showiman, S.S.; Mabkhot, Y.N. C, N-bipyrazole receptor grafted onto a porous silica surface as a novel adsorbent based polymer hybrid. Talanta 2015, 143, 1-6. [CrossRef]

29. Radi, S.; Toubi, Y.; Bacquet, M.; Degoutin, S.; Mabkhot, Y.N.; Garcia, Y. An inorganic-organic hybrid material made of a silica-immobilized Schiff base receptor and its preliminary use in heavy metal removal. RSC Adv. 2016, 6, 34212-34218. [CrossRef]

30. Hu, J.; Liu, L.; Xiao, Z. Adsorptions of Cd (II) and methylene blue from aqueous solution by silica hybrid hollow spheres. RSC Adv. 2015, 5, 68092-68098. [CrossRef]

31. Zheng, X.; Wang, C.; Dai, J.; Shi, W.; Yan, Y. Design of mesoporous silica hybrid materials as sorbents for the selective recovery of rare earth metals. J. Mater. Chem. A 2015, 3, 10327-10335. [CrossRef]

32. Thomas, D.W.; Martell, A.E. Metal Chelates of Tetraphenylporphine and of some p-Substituted Derivatives1, 2. J. Am. Chem. Soc. 1959, 81, 5111-5119. [CrossRef]

33. Di Natale, C.; Monti, D.; Paolesse, R. Chemical sensitivity of porphyrin assemblies. Mater. Today 2010, 13, 46-52. [CrossRef]

34. Ishihara, S.; Labuta, J.; Van Rossom, W.; Ishikawa, D.; Minami, K.; Hill, J.P.; Ariga, K. Porphyrin-based sensor nanoarchitectonics in diverse physical detection modes. Phys. Chem. Chem. Phys. 2014, 16, 9713-9746. [CrossRef]

35. Kadish, K.; Smith, K.; Guilard, R. The Porphyrin Handbook. In Biochemistry and Binding: Activation of Small Molecules; Academic Press: Cambridge, MA, USA, 2000; Volume 4.

36. Gamelas, S.; Gomes, A.; Moura, N.; Faustino, M.; Cavaleiro, J.; Lodeiro, C.; Veríssimo, M.; Fernandes, T.; Daniel-da-Silva, A.; Gomes, M.; et al. N-Confused Porphyrin Immobilized on Solid Supports: Synthesis and Metal Ions Sensing Efficacy. Molecules 2018, 23, 867. [CrossRef]

37. Moura, N.M.M.; Nunez, C.; Santos, S.M.; Faustino, M.A.F.; Cavaleiro, J.A.S.; Neves, M.; Capelo, J.L.; Lodeiro, C. Synthesis, Spectroscopy Studies, and Theoretical Calculations of New Fluorescent Probes Based on Pyrazole Containing Porphyrins for Zn(II), Cd(II), and $\mathrm{Hg}(\mathrm{II})$ Optical Detection. Inorg. Chem. 2014, 53, 6149-6158. [CrossRef]

38. Moura, N.M.M.; Nunez, C.; Santos, S.M.; Faustino, M.A.F.; Cavaleiro, J.A.S.; Paz, F.A.A.; Neves, M.; Capelo, J.L.; Lodeiro, C. A New 3,5-Bisporphyrinylpyridine Derivative as a Fluorescent Ratiometric Probe for Zinc Ions. Chem. Eur. J. 2014, 20, 6684-6692. [CrossRef]

39. Shirsat, M.D.; Sarkar, T.; Kakoullis, J., Jr.; Myung, N.V.; Konnanath, B.; Spanias, A.; Mulchandani, A. Porphyrin-functionalized single-walled carbon nanotube chemiresistive sensor arrays for VOCs. J. Phys. Chem. C 2012, 116, 3845-3850. [CrossRef]

40. Suslick, K.S.; Rakow, N.A.; Kosal, M.E.; Chou, J.-H. The materials chemistry of porphyrins and metalloporphyrins. J. Porphyr. Phthalocyanines 2000, 4, 407-413. [CrossRef]

41. Kadish, K.M.; Smith, K.M.; Guilard, R. Handbook of porphyrin science. World Sci. Singap. 2010, 2014, 1-35.

42. Cerqueira, A.; Moura, N.; Serra, V.; Faustino, M.; Tomé, A.; Cavaleiro, J.; Neves, M. $\beta$-Formyl- and $\beta$-Vinylporphyrins: Magic Building Blocks for Novel Porphyrin Derivatives. Molecules 2017, 22, 1269. [CrossRef]

43. Amao, Y.; Miyashita, T.; Okura, I. Platinum tetrakis(pentafluorophenyl)porphyrin immobilized in polytrifluoroethylmethacrylate film as a photostable optical oxygen detection material. J. Fluor. Chem. 2001, 107, 101-106. [CrossRef]

44. Mesquita, M.Q.; Menezes, J.C.J.M.D.S.; Pires, S.M.G.; Neves, M.G.P.M.S.; Simões, M.M.Q.; Tomé, A.C.; Cavaleiro, J.A.S.; Cunha, Â.; Daniel-da-Silva, A.L.; Almeida, A.; et al. Pyrrolidine-fused chlorin photosensitizer immobilized on solid supports for the photoinactivation of Gram negative bacteria. Dyes Pigm. 2014, 110, 123-133. [CrossRef]

45. Huang, G.; Mo, L.-Q.; Cai, J.-L.; Cao, X.; Peng, Y.; Guo, Y.-A.; Wei, S.-J. Environmentally friendly and efficient catalysis of cyclohexane oxidation by iron meso-tetrakis(pentafluorophenyl)porphyrin immobilized on zinc oxide. Appl. Catal. B 2015, 162, 364-371. [CrossRef] 
46. Barbosa, I.A.; de Sousa Filho, P.C.; da Silva, D.L.; Zanardi, F.B.; Zanatta, L.D.; de Oliveira, A.J.A.; Serra, O.A.; Iamamoto, Y. Metalloporphyrins immobilized in Fe3O4@SiO2 mesoporous submicrospheres: Reusable biomimetic catalysts for hydrocarbon oxidation. J. Colloid Interface Sci. 2016, 469, 296-309. [CrossRef]

47. Zanatta, L.D.; Barbosa, I.A.; Zanardi, F.B.; de Sousa Filho, P.C.; Bolzon, L.B.; Ramos, A.P.; Serra, O.A.; Iamamoto, Y. Hydrocarbon oxidation by iron-porphyrin immobilized on SBA-15 as biomimetic catalyst: Role of silica surface. RSC Adv. 2016, 6, 104886-104896. [CrossRef]

48. Castro, K.A.D.F.; Moura, N.M.M.; Fernandes, A.; Faustino, M.A.F.; Simões, M.M.Q.; Cavaleiro, J.A.S.; Nakagaki, S.; Almeida, A.; Cunha, Â.; Silvestre, A.J.D.; et al. Control of Listeria innocua biofilms by biocompatible photodynamic antifouling chitosan based materials. Dyes Pigm. 2017, 137, 265-276. [CrossRef]

49. Costa, J.I.; Tomé, A.C.; Neves, M.G.; Cavaleiro, J.A. 5, 10, 15, 20-tetrakis (pentafluorophenyl) porphyrin: A versatile platform to novel porphyrinic materials. J. Porphyr. Phthalocyanines 2011, 15, 1116-1133. [CrossRef]

50. Mutneja, R.; Singh, R.; Kaur, V.; Wagler, J.; Fels, S.; Kroke, E. Schiff base tailed silatranes for the fabrication of functionalized silica based magnetic nano-cores possessing active sites for the adsorption of copper ions. New J. Chem. 2016, 40, 1640-1648. [CrossRef]

51. Apak, R.; Tütem, E.; Hügül, M.; Hizal, J. Heavy metal cation retention by unconventional sorbents (red muds and fly ashes). Water Res. 1998, 32, 430-440. [CrossRef]

52. Şen, P.; Hirel, C.; Andraud, C.; Aronica, C.; Bretonnière, Y.; Mohammed, A.; Ågren, H.; Minaev, B.; Minaeva, V.; Baryshnikov, G. Fluorescence and FTIR spectra analysis of trans-A2B2-substituted di-and tetra-phenyl porphyrins. Materials 2010, 3, 4446-4475. [CrossRef]

53. Arakaki, L.; Filha, V.A.; Germano, A.; Santos, S.; Fonseca, M.; Sousa, K.; Espínola, J.; Arakaki, T. Silica gel modified with ethylenediamine and succinic acid-adsorption and calorimetry of cations in aqueous solution. Thermochim. Acta 2013, 556, 34-40. [CrossRef]

54. Yin, P.; Tian, Y.; Wang, Z.; Qu, R.; Liu, X.; Xu, Q.; Tang, Q. Synthesis of functionalized silica gel with poly (diethylenetriamine bis (methylene phosphonic acid)) and its adsorption properties of transition metal ions. Mater. Chem. Phys. 2011, 129, 168-175. [CrossRef]

55. Dai, B.; Cao, M.; Fang, G.; Liu, B.; Dong, X.; Pan, M.; Wang, S. Schiff base-chitosan grafted multiwalled carbon nanotubes as a novel solid-phase extraction adsorbent for determination of heavy metal by ICP-MS. J. Hazard. Mater. 2012, 219, 103-110. [CrossRef]

56. Zhang, Y.; Qu, R.; Sun, C.; Wang, C.; Ji, C.; Chen, H.; Yin, P. Chemical modification of silica-gel with diethylenetriamine via an end-group protection approach for adsorption to $\mathrm{Hg}$ (II). Appl. Surf. Sci. 2009, 255, 5818-5826. [CrossRef]

57. Pérez-Quintanilla, D.; Sánchez, A.; del Hierro, I.; Fajardo, M.; Sierra, I. Preparation, characterization, and Zn 2+ adsorption behavior of chemically modified MCM-41 with 5-mercapto-1-methyltetrazole. J. Colloid Interface Sci. 2007, 313, 551-562. [CrossRef]

58. Brunauer, S.; Emmett, P.H.; Teller, E. Adsorption of gases in multimolecular layers. J. Am. Chem. Soc. 1938, 60, 309-319. [CrossRef]

59. Banerjee, I.A.; Yu, L.; Matsui, H. Cu nanocrystal growth on peptide nanotubes by biomineralization: Size control of Cu nanocrystals by tuning peptide conformation. PNAS 2003, 100, 14678-14682. [CrossRef]

60. Liu, W.; Yin, P.; Liu, X.; Dong, X.; Zhang, J.; Xu, Q. Thermodynamics, kinetics, and isotherms studies for gold (III) adsorption using silica functionalized by diethylenetriaminemethylenephosphonic acid. Chem. Eng. Res. Des. 2013, 91, 2748-2758. [CrossRef]

61. Fang, G.-Z.; Tan, J.; Yan, X.-P. An ion-imprinted functionalized silica gel sorbent prepared by a surface imprinting technique combined with a sol- gel process for selective solid-phase extraction of cadmium (II). Anal. Chem. 2005, 77, 1734-1739. [CrossRef]

62. Najafi, M.; Yousefi, Y.; Rafati, A. Synthesis, characterization and adsorption studies of several heavy metal ions on amino-functionalized silica nano hollow sphere and silica gel. Sep. Purif. Technol. 2012, 85, 193-205. [CrossRef]

63. Miao, J.; Qian, J.; Wang, X.; Zhang, Y.; Yang, H.; He, P. Synthesis and characterization of ordered mesoporous silica by using polystyrene microemulsion as templates. Mater. Lett. 2009, 63, 989-990. [CrossRef]

64. Mureseanu, M.; Reiss, A.; Cioatera, N.; Trandafir, I.; Hulea, V. Mesoporous silica functionalized with 1-furoyl thiourea urea for $\mathrm{Hg}$ (II) adsorption from aqueous media. J. Hazard. Mater. 2010, 182, 197-203. [CrossRef] 
65. Synytsya, A.; Synytsya, A.; Blafková, P.; Ederová, J.; Spěvaček, J.; Slepička, P.; Král, V.; Volka, K. $\mathrm{pH}$-Controlled Self-Assembling of meso-Tetrakis(4-sulfonatophenyl)porphyrin-Chitosan Complexes. Biomacromolecules 2009, 10, 1067-1076. [CrossRef]

66. Roumeliotis, P.; Kurganov, A.; Davankov, V. Effect of the hydrophobic spacer in bonded [Cu (l-hydroxyprolyl) alkyl]+ silicas on retention and enantioselectivity of $\alpha$-amino acids in high-performance liquid chromatography. J. Chromatogr. A 1983, 266, 439-450. [CrossRef]

67. Kudryavtsev, G.; Mil'chenko, D.; Bernadyuk, S.; Vertinskaya, T.; Lisichkin, G. Synthesis and properties of phosphate cation-exchangers based on silica. Theor. Exp. Chem. 1988, 23, 658-663. [CrossRef]

68. Radi, S.; El Abiad, C.; Moura, N.M.; Faustino, M.A.; Neves, M.G.P. New Hybrid Adsorbent Based on Porphyrin Functionalized Silica for Heavy Metals Removal: Synthesis, Characterization, Isotherms, Kinetics and Thermodynamics Studies. J. Hazard. Mater. 2017. [CrossRef]

69. Sanders, J.K.; Bampos, N.; Clyde-watson, Z.; Darling, S.L.; Hawley, J.C.; KIM, H.-J.; Mak, C.C.; Webb, S.J. Axial Coordination Chemistry 15 of Metalloporphyrins. Porphyr. Handb. Inorg. Organomet. Coord. Chem. 2000, 3, 1 .

70. De Luca, G.; Romeo, A.; Scolaro, L.M.; Ricciardi, G.; Rosa, A. Sitting-atop metallo-porphyrin complexes: Experimental and theoretical investigations on such elusive species. Inorg. Chem. 2009, 48, 8493-8507. [CrossRef]

71. Munro, O.Q.; Bradley, J.C.; Hancock, R.D.; Marques, H.M.; Marsicano, F.; Wade, P.W. Molecular mechanics study of the ruffling of metalloporphyrins. J. Am. Chem. Soc. 1992, 114, 7218-7230. [CrossRef]

72. Sanders, J.K.M.; Bampos, N.; Clyde-Watson, Z.; Darling, S.L.; Hawley, J.C.; Kim, H.-J.; Ching, C.; Webb, S.J. Axial Coordination Chemistry of Metalloporphyrins; Academic Press: Singapore, 2000; Volume 3.

73. Limousin, G.; Gaudet, J.-P.; Charlet, L.; Szenknect, S.; Barthes, V.; Krimissa, M. Sorption isotherms: A review on physical bases, modeling and measurement. Appl. Geochem. 2007, 22, 249-275. [CrossRef]

74. Shi, H.; Li, W.; Zhong, L.; Xu, C. Methylene blue adsorption from aqueous solution by magnetic cellulose/graphene oxide composite: Equilibrium, kinetics, and thermodynamics. Ind. Eng. Chem. Res. 2014, 53, 1108-1118. [CrossRef]

75. Azouaou, N.; Sadaoui, Z.; Djaafri, A.; Mokaddem, H. Adsorption of cadmium from aqueous solution onto untreated coffee grounds: Equilibrium, kinetics and thermodynamics. J. Hazard. Mater. 2010, 184, 126-134. [CrossRef] [PubMed]

76. Albadarin, A.B.; Mangwandi, C.; Ala'a, H.; Walker, G.M.; Allen, S.J.; Ahmad, M.N. Kinetic and thermodynamics of chromium ions adsorption onto low-cost dolomite adsorbent. Chem. Eng. J. 2012, 179, 193-202. [CrossRef]

77. Salvestrini, S.; Leone, V.; Iovino, P.; Canzano, S.; Capasso, S. Considerations about the correct evaluation of sorption thermodynamic parameters from equilibrium isotherms. J. Chem. Thermodyn. 2014, 68, 310-316. [CrossRef]

78. Tran, H.N.; You, S.-J.; Hosseini-Bandegharaei, A.; Chao, H.-P. Mistakes and inconsistencies regarding adsorption of contaminants from aqueous solutions: A critical review. Water Res. 2017, 120, 88-116. [CrossRef]

79. Hamad, H.; Ezzeddine, Z.; Kanaan, S.; Lakis, F.; Hijazi, A.; Moussawi, M.-A. A novel modification and selective route for the adsorption of $\mathrm{Pb} 2+$ by oak charcoal functionalized with glutaraldehyde. Adv. Powder Technol. 2016, 27, 631-637. [CrossRef]

80. Koorepazan Moftakhar, M.; Dousti, Z.; Yaftian, M.R.; Ghorbanloo, M. Investigation of heavy metal ions adsorption behavior of silica-supported Schiff base ligands. Desalin. Water Treat. 2016, 57, 27396-27408. [CrossRef]

81. Radi, S.; Tighadouini, S.; Bacquet, M.; Degoutin, S.; Janus, L.; Mabkhot, Y.N. Fabrication and covalent modification of highly chelated hybrid material based on silica-bipyridine framework for efficient adsorption of heavy metals: Isotherms, kinetics and thermodynamics studies. RSC Adv. 2016, 6, 82505-82514. [CrossRef]

82. Radi, S.; Tighadouini, S.; Baquet, M.; Zaghrioui, M. New adsorbent material based on nitrothiophene-functionalized silica particles for aqueous heavy metals removal. J. Sulfur Chem. 2016, 37, 296-306. [CrossRef]

83. Fan, H.-T.; Sun, X.-T.; Zhang, Z.-G.; Li, W.-X. Selective removal of lead (II) from aqueous solution by an ion-imprinted silica sorbent functionalized with chelating N-donor atoms. J. Chem. Eng. Data 2014, 59, 2106-2114. [CrossRef] 
84. Radi, S.; Tighadouini, S.; El Massaoudi, M.; Bacquet, M.; Degoutin, S.; Revel, B.; Mabkhot, Y.N. Thermodynamics and kinetics of heavy metals adsorption on silica particles chemically modified by conjugated $\beta$-ketoenol furan. J. Chem. Eng. Data 2015, 60, 2915-2925. [CrossRef]

85. Wang, Z.; Wang, M.; Wu, G.; Wu, D.; Wu, A. Colorimetric detection of copper and efficient removal of heavy metal ions from water by diamine-functionalized SBA-15. Dalton Trans. 2014, 43, 8461-8468. [CrossRef] [PubMed]

86. Zhu, Z. Preparation and characterization of functionalized silica spheres for removal of $\mathrm{Cu}$ (II), $\mathrm{Pb}$ (II), $\mathrm{Cr}$ (VI) and Cd (II) from aqueous solutions. RSC Adv. 2015, 5, 28624-28632. [CrossRef]

87. Wang, F.P.; Li, G.F.; Zhou, Q.Q.; Yang, C.X.; Wang, Q.Z. Removal of metal ions from aqueous solution with $\beta$-cyclodextrin-based hydrogels. Mater. Express 2016, 6, 394-402. [CrossRef]

88. Parambadath, S.; Mathew, A.; Park, S.S.; Ha, C.-S. Pentane-1, 2-dicarboxylic acid functionalized spherical MCM-41: A simple and highly selective heterogeneous ligand for the adsorption of Fe 3+ from aqueous solutions. J. Environ. Chem. Eng. 2015, 3, 1918-1927. [CrossRef]

89. He, S.; Zhao, C.; Yao, P.; Yang, S. Chemical modification of silica gel with multidentate ligands for heavy metals removal. Desalin. Water Treat. 2016, 57, 1722-1732. [CrossRef]

90. Liang, Z.; Shi, W.; Zhao, Z.; Sun, T.; Cui, F. The retained templates as "helpers" for the spherical meso-silica in adsorption of heavy metals and impacts of solution chemistry. J. Colloid Interface Sci. 2017, 496, 382-390. [CrossRef]

91. Tamez, C.; Hernandez, R.; Parsons, J. Removal of $\mathrm{Cu}$ (II) and $\mathrm{Pb}$ (II) from aqueous solution using engineered iron oxide nanoparticles. Microchem J. 2016, 125, 97-104. [CrossRef]

92. Ghorbani, M.; Nowee, S.M.; Ramezanian, N.; Raji, F. A new nanostructured material amino functionalized mesoporous silica synthesized via co-condensation method for $\mathrm{Pb}$ (II) and $\mathrm{Ni}$ (II) ion sorption from aqueous solution. Hydrometallurgy 2016, 161, 117-126. [CrossRef]

93. Tighadouini, S.; Radi, S.; Bacquet, M.; Degoutin, S.; Zaghrioui, M.; Jodeh, S.; Warad, I. Removal efficiency of $\mathrm{Pb}$ (II), Zn (II), Cd (II) and Cu (II) from aqueous solution and natural water by ketoenol-pyrazole receptor functionalized silica hybrid adsorbent. Sep. Sci. Technol. 2017, 52, 608-621. [CrossRef]

94. Radi, S.; Tighadouini, S.; Bacquet, M.; Degoutin, S.; Garcia, Y. New hybrid material based on a silica-immobilised conjugated $\beta$-ketoenol-bipyridine receptor and its excellent $\mathrm{Cu}$ (ii) adsorption capacity. Anal. Methods 2016, 8, 6923-6931. [CrossRef]

95. Xue, X.; Li, F. Removal of Cu (II) from aqueous solution by adsorption onto functionalized SBA-16 mesoporous silica. Microporous Mesoporous Mater. 2008, 116, 116-122. [CrossRef]

Sample Availability: Sample of the hybrid SiTF5PP is available from the authors.

(C) 2019 by the authors. Licensee MDPI, Basel, Switzerland. This article is an open access article distributed under the terms and conditions of the Creative Commons Attribution (CC BY) license (http:/ / creativecommons.org/licenses/by/4.0/). 